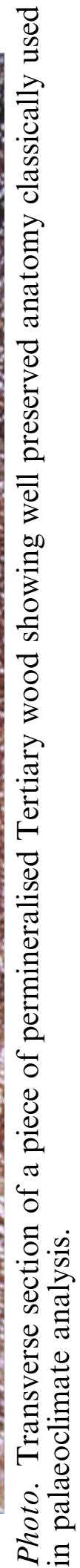




\title{
Physiognomic and chemical characters in wood as palaeoclimate proxies
}

\author{
Imogen Poole ${ }^{1,2,3, *}$ and Pim F. van Bergen ${ }^{3,4}$ \\ ${ }^{1}$ Palaeontological Museum, Oslo University, 1172, Blindern, N0318, Oslo, Norway; ${ }^{2}$ National Herbarium of \\ the Netherlands, University of Utrecht Branch, Utrecht University, Utrecht, The Netherlands; ${ }^{3}$ Geochemistry, \\ Earth Sciences, Utrecht University, 80021, 3508 TA, Utrecht, The Netherlands; ${ }^{4}$ Shell Global Solutions, Flow \\ Assurance, 38000, 1030 BN, Amsterdam, The Netherlands; *Author for correspondence (e-mail: \\ i.poole@geo.uu.nl)
}

Received 1 September 2004; accepted in revised form 15 December 2004

Key words: Fossil wood, Lignin, Stable Isotopes, Tree rings

\begin{abstract}
Fossil wood is both abundant and ubiquitous through geological time and space. During growth the parent plant was directly influenced by the biotic and abiotic (including climatic-) factors in the surrounding environment. The climate affects wood production in a number of ways and it is the resulting physiognomic and chemical characters that can help retrodict palaeoclimate. Physiognomic characters include those morphological and anatomical characters that in turn have enabled the use of wood characters, tree ring characters and statistical parameters (Mean Sensitivity) to determine seasonality, length and favourability of growing season, growth rates and forest productivity. Potential chemical characters discussed include (i) the preservation of wood-derived compounds (e.g. guaiacyl, syringyl p-hydroxyphenyl and resins); (ii) degree of lignin degradation to determine climate induced environmental changes; and (iii) stable isotopes $\left(\delta \mathrm{D}, \delta^{13} \mathrm{C}\right.$ and $\left.\delta^{18} \mathrm{O}\right)$ to help determine aspects of past climates as derived from environmental changes. The feasibility and methodology of these characters, in both angiosperm and conifer wood, are reviewed in order to establish certain safe guards, or prerequisites, such that interpretations of palaeoclimate can be as unbiased, and thus as reliable, as possible.
\end{abstract}

\section{Introduction}

Due to its omnipresence in sequences through geological time coupled with its robust nature, wood has provided researchers with a potentially rich archive of data impinging on areas as diverse as the evolution of arborescence and biodiversity to chemical taphonomy and palaeoclimate. Such data are used to glimpse past environments often quite unlike those with which we are familiar today. Fossil plants often represent the remains of shrub and canopy-forming organisms thus are particularly important in palaeoecological reconstructions. Palaeoecology, in its loosest sense, circumscribes all biotic and abiotic factors that existed together during geological time. One such abiotic factor, which has caught the attention of the scientific community in recent years, is past (i.e. historical to Quaternary) and palaeo- (i.e. preQuaternary) climate (both referred to as 'palaeoclimate' herein for convenience unless otherwise stated). This biological input to our understanding of palaeoclimate presents an important parameter that can be used to help calibrate computergenerated models based on physical data (Taylor et al. 1992; Poole et al. 2003).

Before we undertake a critical review of the potential aspects of wood as a palaeoclimate proxy it is necessary to introduce the concept of variation which underpins data interpretation obtained from 
living organisms. Unfortunately living organisms do not readily submit to our attempts to neatly categorise them and the natural variation expressed, whether at the chemical or physiognomic level, needs due consideration such that interpretations can be as reliable as currently possible (Poole 2000). It would be misleading to imply that variation has not been considered. In fact variation in observed wood characters has been known since $300 \mathrm{BC}$ through the recordings of Theophrastus (Carlquist 1988). Moreover, disciplines have arisen from acknowledging variation such that variation is used to obtain reliable, rigorous data. For example dendrochronology (see below) utilises anatomical variation whilst forestry science exploits the genetic variation in commercially important technological characters of wood. Other disciplines, including palaeoclimatology, have been slower to recognise and account for variation thus rendering comparisons more tenuous. One of the most important sources of variability in wood is related to its ontogenetic age and growth position within the plant, i.e. whether it is derived from trunk, branch, stump or root material (Jane 1962; Chapman 1994; Gartner 1995; Falcon-Lang 2005a), in addition to chemical variations even at the cell wall layer level (van der Heijden and Boon 1994; van der Heijden et al. 1994). Such intra-tree variability can often be greater than the average values for inter-tree variability from the same or even different sites (Larsen 1967). This highlights the fundamental importance of providing as much information about the fossil material under investigation as possible.

This chapter is subdivided into two parts. Section 'Macroscopic characters of wood' reviews the macroscopic features of wood used in palaeoclimate reconstructions whereas Section 'Chemical characters of wood' focuses on specific chemical characters of wood to this end. When discussing the applicability of the different aspects of wood characters as proxies for palaeoclimate we bear in mind the potential sources of bias and outline means to circumvent them.

\section{Macroscopic characters of wood}

\section{Taxonomic based methodology}

Latitude is one of many factors that help determine the climate within an area. In turn the climate is one of the major determinants for plant growth. Studies of palaeoclimate have traditionally used a bioclimatic approach (Kershaw and Nix 1988) utilising the nearest living relative (NLR) principal (e.g. Mosbrugger 1999). This relies on the premise that there has been little change in the climatic preference of a particular plant fossil taxon relative to its NLR today. This approach is therefore linked to botanical affinities and nomenclature of identified fossils (Collinson 1986; Mosbrugger 1999). Critics amongst us would be quick to point out that ecological tolerances of plants are unlikely to have remained unchanged during geological time and for isolated organs, such as wood, identification to a living relative is tenuous without attached reproductive structures not to mention problems introduced by sampling strategies and taphonomical biases. Indeed there are very few cases published where the identity of fossil wood can be confirmed by the presence of attached reproductive organs (e.g. Herendeen 1991). To help overcome this Mosbrugger and Utescher (1997) refined this bioclimatic methodology in order to quantify terrestrial climate reconstructions in the Tertiary based on the bioclimatic appraisal of fossil floras. They coined their method the Coexistence Approach (CoA). This approach can be made relatively more rigorous by restricting the extrapolation to the recent past.

Such bioclimatic approaches have usually focused on fruit and seed or leaf floras (e.g. Reid and Chandler 1933; Liang et al. 2003) but there is no reason why it cannot be applied to fossil wood floras (Poole, Cantrill and Utescher 2005). Sceptics may suggest that a wood flora, as opposed to a palynological flora, would not accurately represent the parent vegetation and thus climate. However, a study of trunks greater than $10 \mathrm{~cm}$ in diameter lying in palisadas along the river Manu (Peru) showed a statistically highly significant representation of the local vegetation when the material was identified to family or genus level (Poole, Silman and van Bergen unpublished data). This indicates that although not necessarily complete (but certainly complements and supplements data derived from other organ floras) and probably representing a relatively local, rather than regional flora, fossil wood alone goes a long way to providing a good representation of the vegetation from which it was derived and thus, by extrapolation, the palaeoclimate. 
As with any organ a bioclimatic approach hinges on a good working knowledge of wood anatomy of both living and fossil material such that the fossil can be identified to a 'nearest living relative'. Applying this method to fossil wood floras is routinely carried out to study former ecosystems and assess changes in vegetational communities over time (Figueiral and Mosbrugger 2000). For example Wheeler and Manchester (2002) published a study of the diverse fossil wood assemblage from the Clarno Nut Beds. They concluded a probable warm temperate to subtropical climate regime existed over Oregon during the Middle Eocene - a conclusion substantiated by the NLRs of the identified woods which are now growing in eastern/southeastern Asia. Poole et al. (2001) had adopted a bioclimatic approach when they determined that the cool temperate Valdivian rainforests of southern Chile are the modern analogue to Tertiary Antarctic vegetation. Independent climate analyses (Hunt and Poole 2003) of the floras corroborated a prevailing cool temperate climate regime. Moreover, an understanding of both the sedimentary environment and the biotic makeup of the vegetation enabled Poole et al. (2001) to determine that ecological disturbance, in this case volcanic activity, was controlling the vegetational shifts and not climate change to which the shifts had been attributed. This illustrates the importance of looking at all available data through interdisciplinary approaches to ensure accurate and precise palaeoecological and thus palaeoclimatic interpretations.

\section{Physiognomic based methodologies}

Physiognomic based methodologies to determine palaeoclimate assume that morphological or anatomical characters had the same relationship with climate in the past as they do today without needing reference to systematic status of the plant (Liang et al. 2003) but simply relying on relative differences in the character states. Ideally fossil wood studied would be preserved in situ allowing the examination of forest density and productivity as well as analysing morphological and anatomical characters for palaeoclimatic signals. Unfortunately such instances are rare such that isolated wood organs are predominantly the focus of palaeoclimatic studies.
Morphological characters

Most plant fossil assemblages are allochthonous having arrived at their site of incorporation into the geological record after being transported from their parent vegetational community. In situ fossil plants, although more rarely preserved, are considerably more valuable in palaeoenvironmental analysis. Morphological characters of in situ material can provide indications of the hydrological status of the palaeoenvironment and in particular the seasonality and intensity of precipitation (Fielding and Alexander 2001). Fossil trees in the deposits of variable-discharge rivers are generally low in diversity, comprising pioneer plant assemblages and dominated by individuals of limited diameter reflecting typically high mortality rates of plants in such environments (Fielding et al. 1997; Fielding and Alexander 2001). Moreover, morphological adaptations to periodic submergence may be determined from characters such as trailing roots (conversely thick, spongy roots would be indicative of adaptations to dry seasons), reclined habit, multi-stemmed forms, concentration of individuals in flow-parallel linear grooves, thick, spongy bark (e.g. Hook 1984; Fielding and Alexander 2001; van der Burgh in Poole et al. submitted). In extreme cases following long periods of coverage by standing water or sediment, trunks may have flask-shaped basal portions and/or a second root layer on top of the newly deposited sediment (Stone and Vasey 1968; Jefferson 1982). These morphological specialisations would be in response to the stresses imparted through the need to successfully inhabit a riverbed environment and to ensure access to moisture during the dry season. However, palaeoclimatic interpretation from such assemblages obviously relies on fossil tree morphology in conjunction with analysis of the associated sediments (Demko et al. 1998).

\section{Anatomical characters}

Data provided by fossil wood anatomical characters have been used extensively to reconstruct climates and determining climate change during the geological past. Both conifer and angiosperm woods have been employed to this end. The activity of a particular layer of cells, the vascular cambium, located in the bark is responsible for wood formation. Factors influencing cambial activity (see Creber and Chaloner 1990 and references therein) usually mediated by growth hormones (e.g. Aloni 
2001) affect the characteristics of the wood cells produced. During unfavourable environments the cessation of cambial cell division leads to the formation of growth rings. Larger diameter cells are produced at the beginning of the growing season (early wood) followed by smaller diameter cells (late wood) as the growing season draws to a close (Figure 1). These anatomical changes help to emphasise the environmentally related growth characteristics within both conifer and angiosperm wood. The wood structure of conifers is relatively simple with a single cell type, tracheid, for both support and water conduction (Figure 1b) whereas dicotyledonous angiosperm (dicot) wood exhibit a division of labour (Wheeler and Baas 1993). Perforate vessel elements undertake water conduction whereas imperforate fibres provide support (Figure 1c; Jane 1962; Wilson and White 1986; Carlquist 2001 and references therein for further details on wood anatomy and function). Dicot wood is further complicated by the diversity in size, arrangement and minute features of vessel elements which have considerable homoplasy (Wheeler and Baas 1993). Based on extensive floristic surveys certain wood anatomical features can be characteristic of certain ecological categories (e.g.
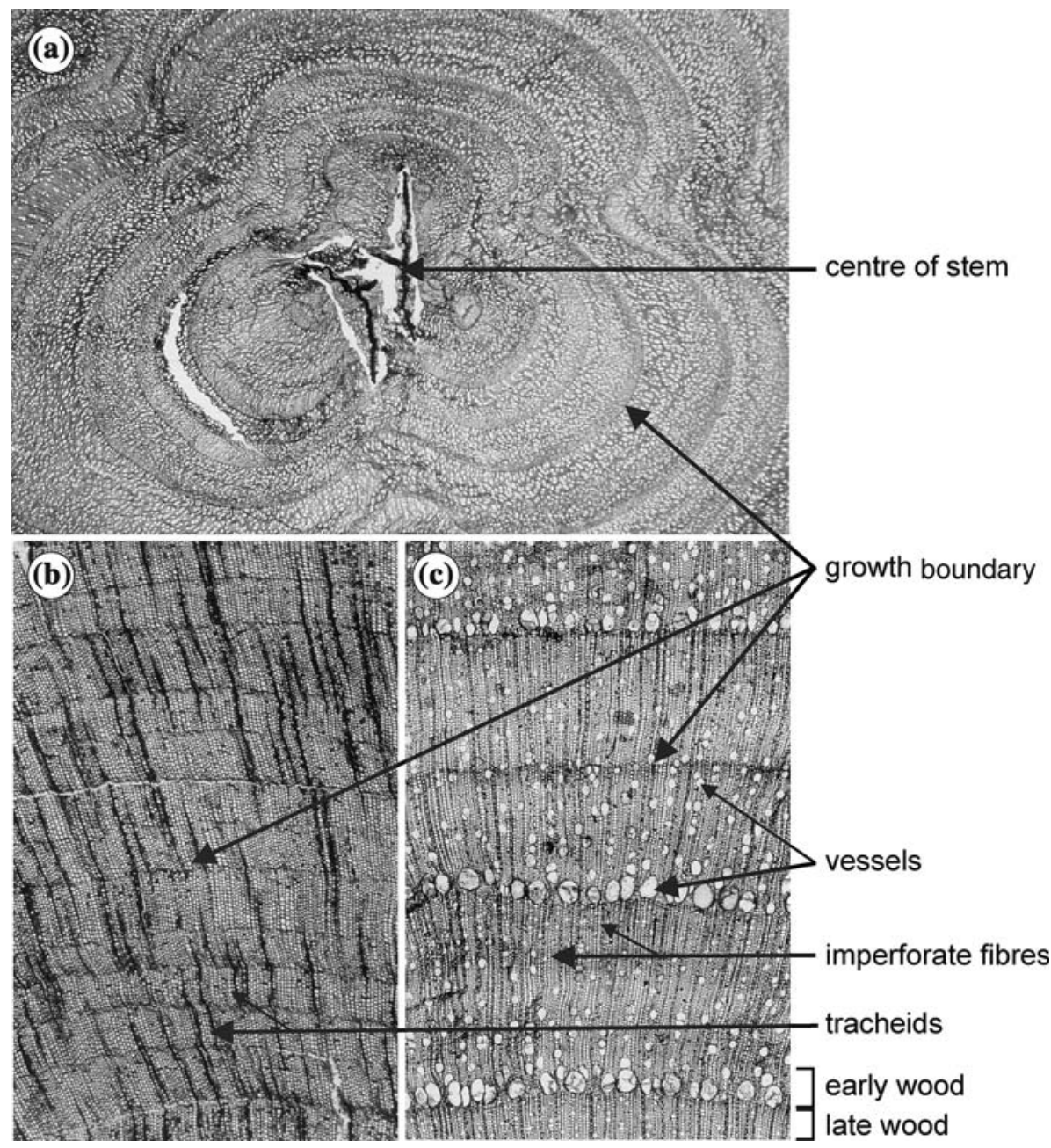

Figure 1. Tertiary fossil wood. (a) Permineralised branch wood from a dicotyledonous angiosperm from Antarctica showing the distinctive growth rings. (b) Mummified conifer wood from Tasmania, Australia showing the relatively simple structure of conifer wood. Growth rings are demarcated by $\sim 2$ rows of late wood tracheids. (c) Permineralised angiosperm wood from Antarctica showing growth rings defined by the increase in wall thickening of the imperforate tracheary elements and emphasised by the increased vessel diameter in the early wood relative to the late wood. 
Carlquist 1975, 1977, 2001; Baas 1976, 1986; Wiemann et al. 1998, 1999), which in turn are often climate influenced.

Tree rings. Tree rings are probably the most well know anatomical feature used to make generalisations concerning palaeoclimate since tree rings, length and seasonality of the growing season are intimately related. Tree ring analyses for palaeoclimatological inferences rest upon uniformitarian deductions based on observations of (predominantly) conifers from the present boreal temperate realm (Brison et al. 2001) regardless of the incoherent growth rings patterns exhibited by woods growing in warm climates (Jacoby 1989; Worbes 1989, 1995; 1999; Borchert 1999). Understanding sequences of growth ring forms the basis of Dendrochronology which includes the discipline Dendroclimatology. By judicious sampling and the use of rigorous statistical procedures dendroclimatology has provided unique insights into the nature of past climatic variability most significantly from an interannual to centennial time-scale (Briffa et al. 1998) from woods originating from temperate regions. These climate changes reveal themselves as characteristic rings which can be cross matched to overlapping ring series from different trees thereby extending the climate record (ideally) uninterrupted into the past. The success of using growth rings to determine (cool temperate) climate from the past has led palaeoclimatologists to use this methodology on older material even though some researchers consider this approach questionable for pre-Quaternary fossils (e.g. Ammons et al. 1987; Falcon-Lang 2003, 2005b).

Although growth rings in essence appear to be a rich archive of palaeoclimatic information, careful evaluation of the material for study is paramount to ensure that the climate signal is not being confused with expressions of variation which in turn would affect wood growth and growth ring characters (see Creber and Chaloner 1984; Briffa et al. 1998; Tardif et al. 2003). Problems arise from restricted biotic (including genetic) and abiotic effects often surpassing the climate effect. Moreover, not all tree species conveniently lend themselves to such an approach (see Schweingruber 1993 for listings). Within the tropical realm there is no simple correlation between climate and the development of growth rings since the ability to produce rings is primarily determined by the genetic makeup of the individual species (e.g. Chowdhury 1964; Tomlinson and Craighead 1972; Jacoby 1989; Savidge 1996) and exposure to inundation resulting in cessation of growth (Worbes 1985, 1989). Studies of inter-tree variability find that within a given tree many anatomical parameters show significant relationship with (i) taxonomic status (see Schweingruber 1993), (ii) ontogenetic age (fast growing young trees have wider, more variable rings compared with older more slow growing trees which can have missing rings), and (iii) organ of origin: branch wood can be affected by unequal gravitational forces producing 'reaction' and 'compression' wood, and root wood and twig material have wider growth rings than trunk wood (Jane 1962; Zobel and van Buijtenen 1989; Chapman 1994; Falcon-Lang 2003, 2005a). Ring patterns are only meaningful if derived from known organs seen in relation to the whole diameter since ring boundaries can become gradually narrower and fainter when traced around the trunk, some do not even make a full circuit; rings can also 'wedge out' from other rings. This results in confused growth interruptions (see Larson 1956 for physiological explanations) with a growth ring series from one radius not obviously relating to a series complied from another radius from the same cross section (Ash and Creber 1992).

In situ fossil tree stumps provide relatively rigorous, cross-dateable datasets to retrodict palaeoclimate at a particular locality even if such chronologies are "floating" (Jefferson 1982; Ammons et al. 1987; Gregory-Wodzicki 2001). Where such studies are possible, biologically induced growth cycles can be eliminated and sedimentological evidence can be used to help determine (local) environmental (e.g. Falcon-Lang et al. 2001) conditions (Ammons et al. 1987) ensuring more rigorous palaeoclimate interpretation. Since in situ material is rare, isolated wood specimens become the focus of attention for palaeoclimate analysis.

When extending the growth ring analysis approach to pre-Quaternary isolated wood material ideally a number of prerequisites need to be met:

(i) assemblages need to be of an adequate sample size (ca. $>20$ trees) and taxonomically diverse (cf. Wiemann et al. 1998).

(ii) specimens should be identifiable in terms of taxon and ontogenetic age. 
(iii) organs should be of complete cross section and have similar origins (with preference for trunk wood) and excluding the inner xylem near the pith to overcome problems of rapid initial growth, confused growth interruptions and unequal gravitational effects (Fritts 1976; Zobel and Buijtenen 1989).

(iv) taxa should be 'reliable' (see Schweingruber 1993; Falcon-Lang 2000a; Falcon-Lang and Cantrill 2000; Brison et al. 2001).

(v) conifer taxa need to have known leaf longevity/retention times (Falcon-Lang 2000a, b).

Unfortunately with many fossil woods all these prerequisites cannot be fulfilled but adequate reference to both the specific taxon and specimen ontogeny, coupled with a significant but not unrealistic sample size from localities with a tight stratigraphic-, and thus temporal, framework are simple additional precautions that can help distinguish climate signals from background noise. This can reduce the chances of introducing fundamental error and ensure the possibility of legitimate comparative data analyses. So with these prerequisites in mind we explore and discuss the various approaches that have been used to interpret palaeoclimatic factors using growth rings.

Mean sensitivity: To overcome the aforementioned biases introduced through intrinsic and extrinsic factors, statistical parameters have been devised for modern and Quaternary material. The common signal of the impact of any external factor, most likely climate, is assumed to influence the growth of all the trees in the same way with the intrinsic variations exerting a different affect on the tree-ring series. One such statistical parameter that has been adopted for palaeoclimatic research is the 'sensitivity' of tree rings (Creber 1977; Creber and Francis 1999) and in particular the Mean Sensitivity (MS) index (Douglass 1928; Fritts 1976, 1991). MS provides a measure of the variability in growth from year to year and thus an indication of the limitations to growth within the environment. In order to use MS, ring width measurements need to be standardized (Fritts 1976, 1991; Monserud 1986) to remove large amounts of the nonclimatic variations (i.e. ring geometry, age, local stand conditions, site factors, individual tree histories, etc; Fritts 1991; Schweingruber 1993) unique to individual trees and sites and preserve a large part of the climatic variation in ring-width measurements common to trees from a particular region (Fritts 1991).

Mean Sensitivity has been used to help interpret palaeoclimates during the Tertiary and Mesozoic (e.g. Jefferson 1982; Francis 1986; Ammons et al. 1987; Morgans 1999; Morgans et al. 1999; Francis and Poole 2002) even though the standardization procedure has only been implemented in one study to our knowledge (Kumagai et al. 1995). Recent work now shows the use of MS to be inappropriate for both modern (Strackee and Jansma 1992) and fossil (Chapman 1994; Brison et al. 2001; Falcon-Lang 2005a,b) material because of the biases outlined above.

Length and favourability of growing season: Ring width patterns in fossil wood have been used to indicate the length and favourability of the growing season. Consistently wide rings in large diameter fossils can be interpreted as having undergone relatively rapid growth under a favourable climate. The early wood-late wood ratio can help interpretations of length of growing season. Longer, more favourable growing seasons lead to the production of a higher percentage of late wood and a wide zone of early wood followed abruptly by a narrow zone of small, dense late wood cells (cf. Creber 1977; Koizumi et al. 2003; Savva et al. 2003). Unfavourable climatic factors such as fire, frost, drought, increased light towards the end of the growth season (but also biotic factors such as defoliation by insects) can result in a characteristic gradual decrease and subsequent increase in cell diameter, which is not always continuous around the circumference of the tree (but see Schulman 1938 for exceptions), manifesting itself as a 'false' or 'traumatic' ring. However, false rings can be highly localised and often restricted to juvenile wood, upper trunk and lateral branches (Chapman 1994) such that a presence/absence record can result in erroneous 'climatic' indications. Additional biases will arise if spurious rings of collapsed, compacted and flattened cells (formed during burial and diagenesis) are not identified (Chaloner and Creber 1973). Cell characters within a treering are also thought to provide information relating to environmental conditions, such as daylight regime within a growing season at high latitudes (Creber and Francis 1999). Analysis of these characters in fossil wood, particularly if they originate from localities where there is no modern analogue for comparative analysis such as the high 
latitudes, is problematic. For example ring width in fossil woods from the southern high latitudes cannot be related to climatic favourability because a continuous light regime would have ensured elevated growth rates during the growing season (Falcon-Lang et al. 2001).

Seasonality: The markedness of the ring boundary (in particular percentage late wood) has been used as an indicator of climatic seasonality (in precipitation, temperature, etc.) or as a measure of the favourability of growing conditions towards the end of the growing season (Creber and Chaloner 1984; Francis 1986; Ash and Creber 1992; Yao et al. 1994; Keller and Hendrix 1997; Francis and Poole 2002). A high proportion of woods in a fossil assemblage with indistinct growth rings infers a climate that is not highly seasonal (Wheeler and Manchester 2002) and vice versa. However, such extrapolations are drawn from similarities between trees growing at (cool temperate) mid-latitudes today (Vetter and Botosso 1989; Worbes 1989; Lindorf 1994). A combination of factors, such as seasonality in precipitation and (freezing) temperature, alongside other biotic factors (including leaf longevity) and abiotic factors mentioned above can all affect ring markedness (Greguss 1972; Woodcock 1994; Woodcock and Ignas 1994; Falcon-Lang 2000a). LaMarche (1982) went as far to say that in modern conifer woods ring markedness appeared to be poorly correlated with climate since they evolved under high carbon dioxide levels and are still genetically adapted to such conditions.

Deciduous angiosperm plants produce woods of a ring- and/or semi ring porous nature today (Figure 1c; Wheeler and Baas 1991). Therefore, deciduousness could be correlated to seasonality in, for example precipitation, temperature or daylength (Wheeler and Manchester 2002). The earliest know ring porous wood is described from the Cretaceous of Antarctica (Poole et al. 2000) suggesting that this may initially have evolved as an adaptation to pronounced seasonality in day length.

Bias can be introduced because there is a continuum in growth ring boundary markedness and porosity (in dicots) in both extant and fossil wood. Consequently there is not always agreement on the assigned category (e.g. 'ring porous' or 'semi ring porous', etc.) especially over the mid range of this continuum (Wheeler and Manchester 2002).
Overcoming this problem and ensuring consistency in dicot woods might hinge on using continuous vessel characters rather than assigning discrete categories (Woodcock 1994).

Growth rates and forest productivity: Forest productivity estimates can be obtained from in situ stump material using mean ring increment, mean stump diameter and tree density data (see Creber and Francis 1999; Henry and Aarssen 1999) have been successfully applied to in situ forests (e.g. Ash and Creber 1992; Falcon-Lang et al. 2001; Gregory-Wodzicki 2001). Conclusions drawn from such studies become more rigorous still if associated palaeosols are present and interpreted. Relative productivity within a forest can be related to the relative solar input provided the palaeolatitude of the fossil forest is known (see Henry and Aarssen 1999; Creber and Francis 1999). Using isolated fossil material and small diameter material to determine growth rates is not realistic since the biases outlined above become overriding.

Additional dicotyledonous wood anatomical characters. Just as sites that have many species in common can be inferred to have similar climates, sites that have plants with similar anatomical characters could also suggest a similar climate. Modern wood anatomical features specific to dicots have been related to a variety of ecological, and thus climatic, factors (e.g. Baas and Schweingruber 1987; Baas 1973, 1986; Carlquist 1975; den Outer and van Veenendaal 1976; Wheeler and Baas 1991, 1993; February 1993; Woodcock 1994; Woodcock and Ignas 1994; Wiemann et al. 1998; Terral and Mengüal 1999; Baas et al. 2004). A survey of the published fossil dicotyledonous wood records reveal considerable potential for using features of dicot woods as an additional tool in the study of palaeoclimates (Wheeler and Baas 1991; Baas et al. 2004). However, this was only realised when a better understanding was gained into the relationship between qualitative and quantitative wood anatomical data from modern wood and prevailing climate. Temperature-related climate variables, particularly mean annual temperature, yield good correlations with anatomy and were best predicted by two or more wood anatomical characters (Wiemann et al. 1998, 1999, 2001). Using the formulas devised by Wiemann et al. (1998) palaeoclimate can been determined (to within accuracy limits) (Wiemann et al. 1999; Wheeler and 
Manchester 2002; Francis and Poole 2002; Poole et al. submitted). This approach is applicable to Quaternary and Tertiary material since the evolution of wood anatomical features in angiosperms had already been set (Wheeler and Baas 1991; Baas et al. 2004). Adopting these formulae to Cretaceous material introduces the bias of anatomical adaptations since many dicots had only evolved to the shrub- or small tree habit.

In summary anatomical characters, although seemingly a rich source of climate information, will only provide meaningful climate data when derived from fossil material that have met the sample prerequisites. To date, conifer wood has been extensively used to retrodict palaeoclimate. However, recent evidence (Falcon-Lang 2003, 2005a,b) suggests that the variability in modern conifer wood obscures any palaeoclimatic signal except where sample size is very large and sample taxonomy and ontogenetic age is constrained. Such conditions are unlikely to be met in fossil studies rendering the use of quantitative tree ring parameters as indicators of pre-Quaternary climates highly questionable. The use of angiosperm characters to determine palaeoclimate is in its infancy but there is strong evidence to suggest that the quantitative combination of characters might prove to be successful. However, much more data is still required which quantitatively relates modern dicot anatomy to prevailing climate from different ecological habitats.

\section{Chemical characters of wood}

Wood is a complex mixture of distinct chemical compounds that in principal can be used in palaeoclimatic studies. The bulk of wood normally found in the fossil record is secondary xylem and hence this section will focus on the chemical constituents present in this tissue type. Secondary xylem is based primarily on ligno-cellulose complexes. The main constituent is normally the polysaccharide holocellulose (approx. 60-70\%) with a lesser amount of lignin $(30-40 \%)$. In addition, in certain woods solvent extractable compounds, in particular resins, can also contribute up to ca. $5 \%$. It should be noted however, that lignin is not solely derived from secondary xylem but can be found in many other plant organs, including leaves (e.g. van Bergen et al. 1998) and propagules (e.g. Boon et al. 1989; van Bergen et al. 1995; 2004).

Holocellulose can be subdivided further into the cellulose and hemicellulose fractions, with the latter considered to be the bridging units linking cellulose fibres to the lignin macromolecule. Generally, hemicelluloses contribute about $10-20 \%$ to the overall ligno-cellulose complex. Cellulose is a large polymeric molecule based solely on glucose monomers, whereas the hemicelluloses are much smaller units (oligomers) based on a variety of monosaccharides including xylose, mannose and glucose. Xylose is normally the most abundant part of hemicellulose in both dicotyledons and conifers. The difference in chemical composition between these two taxa is mainly based on the abundance of mannose which is often abundant in conifers and much less important in dicotyledons.

In contrast to the chemically well-described polysaccharide component, lignin is a relatively less well-defined aromatic macromolecule considered to be present as a more amorphous matrix surrounding the cellulose microfibres. The building blocks of lignin are based on C9 units: a benzene ring (C6) with an attached $\mathrm{C} 3$ side chain (Appendix I). Units are linked through an oxygen atom attached to the benzene ring to one of the carbons of the side chain (Appendix I). The most common links are the $\beta-\mathrm{O}-4$ and the $\alpha-\mathrm{O}-4$. The benzene ring can contain a number of additional methoxyl groups $\left(-\mathrm{OCH}_{3}\right)$, leading to different basic lignin units. Units with no methoxyl groups are named $p$-hydroxylphenyl (P-units), those with 1 methoxyl adjacent to the $\mathrm{O}$ are called guaiacyl (G-units; also 2-methoxyphenol) and those with two methoxyl groups on either side of the $\mathrm{O}$ are syringyl (S-units; also 2,6-dimethoxylphenol). During lignin formation the individual monomeric lignin units, [ $p$-coumaryl alcohol $(\mathrm{P})$, coniferyl alcohol $(\mathrm{G})$ and sinapyl alcohol (S); Appendix I] present as alcohols with an additional free $\mathrm{OH}$ group in the side chain, are linked at random to form three-dimensional networks.

Different taxa form different monomers leading to distinct chemical compositions of the lignin. Lignin in conifer is based solely on the $G$ units, whereas in all angiosperms the lignin contains at least both $G$ and $S$ although the degree of $G$ vs. $S$ differs dependent on the position within either the secondary xylem or even the cell wall. Amongst the angiosperms, variations are also observed: 
monocotyledons and legumes contain substantial amounts of $\mathrm{P}$ units that are much less important in the non-legume dicotyledons. In addition, monocots and legumes often also contain substantial amounts of cinnamic acids ( $p$-coumaric- and ferulic acid) - compounds very closely related to lignin monomers, but which are mainly ester linked.

Although less ubiquitous than ligno-cellulose, resins can also be found as part of fossil wood remains, in particular those of conifers. Resins of most conifers are based on diterpenoids $\left(\mathrm{C}_{20}\right.$ units $)$ whereas the angiosperms contain resins comprising mainly triterpenoids $\left(\mathrm{C}_{30}\right.$ units) (e.g. Otto and Wilde 2001; Langenheim 2003). Resins can lock up, directly or indirectly, information that might be used for palaeoclimatic reconstructions. As with lignin, chemical differences exist mainly at the angiosperm and conifer level, but further variations occur among the conifer taxa (see Otto and Wilde 2001 for a recent review).

\section{Wood-derived compounds as proxies for palaeoclimate}

Although differences in the actual molecular composition of ligno-cellulose might be climate dependant, we know of no studies applying changes in chemical composition taken directly from fossil wood material. One major complication for such an approach is that the chemical composition of fossil wood, as with the physiognomic characters, may vary depending on ontogenetic age of the material as well as original positioning within the tree. Nevertheless wood-derived compounds can be used to assess changes in vegetation composition and/or depositional setting which in turn can be linked to climatic changes.

\section{Climate induced vegetation changes}

Lignin-derived markers have been used to evaluate changes in vegetation composition which in turn were believed to be climate driven (Hedges et al. 1982; Goñi 1997; Sheng Hu et al. 1999). However, the use of molecular markers only indirectly reflects climate changes. Changes in the ratio of guaiacyl to syringyl $(\mathrm{G} / \mathrm{S})$ and $p$-hydroxyphenyl to guaiacyl, $(\mathrm{P} / \mathrm{G})$ have been applied to organic matter obtained from various settings including lake sediments and deltaic samples. For example, a trend from a warm to a cold period could lead to a change from an angiosperm dominated vegetation to a conifer dominated vegetation which might subsequently be replaced by a grass dominated ecosystem during the coldest period. In such a case one would expect to find first an increase of $\mathrm{G} / \mathrm{S}$ (increase of conifers over angiosperms) and subsequently an increase of $\mathrm{P} / \mathrm{G}$ [increase of monocotyledons - i.e. grasses - relative to conifers].

Climate-induced vegetation changes have also been reported based on wood-derived resins compounds. These were mainly related to changes in the composition of resin-derived markers found in sediment cores. For example, a global cooling trend was inferred from a distinct increase in the relative abundance of retene, a diagenetic compound known to be derived from diterpenoid conifer resins (Simoneit 1998), over cadalene in Jurrasic sediments (van Aarssen et al. 2000; Grice et al. 2001). The increase of retene was suggested to imply larger amounts of conifer derived organic matter entering the marine realm whereby the conifers were considered to be more representative of a cooler climate (van Aarssen et al. 2000). However, an alternative explanation would be that, since this trend co-occurred with a global eustatic sea level rise, larger expanses of conifer dominated hinterland vegetation were being exposed. This illustrates the necessity to work with all available data to ensure accurate palaeoclimatic reconstructions.

\section{Climate induced changes in depositional setting}

Another application of wood derived compounds has been to study the degree of lignin degradation which can be related to climate changes. Detailed molecular studies of peat deposits, to determine differences in the level of degradation, have been evaluated in terms of changes in depositional setting (e.g. Kuder and Kruge 1998). These in turn were believed to be related to regional changes from wetter to drier periods (e.g. Kuder and Kruge 1998). The underlying reasoning was that drier periods would result in more enhanced oxic lignin degradation and thus an increase in more oxygenated lignin degradation products. Thus, ratios of various lignin degradation products can indirectly yield palaeoenvironmental information.

\section{Palaeoclimate signals from stable isotopes in wood}

In addition to the molecular composition of wood, organic compounds lock up palaeoclimate 
information through the presence of stable isotopes of Hydrogen, Carbon and Oxygen, i.e. $\delta \mathrm{D}, \delta^{13} \mathrm{C}$ and $\delta^{18} \mathrm{O}$, respectively. It is beyond the scope of the current paper to review all published data in this research field with the majority focusing on plant material from the recent past. For additional detailed information the reader is referred to the excellent studies for amongst others Epstein, Ehleringer, Leavitt, Loader, Saurer, Schleser (see also http://www.ltrr.arizona.edu/ sleavitt/IsoDendroBib.htm).

Briefly, the stable isotope signals of hydrogen and oxygen measured in plant material are mainly derived from the isotopic composition of the leaf water used by the plant during photosynthesis. This in turn is affected by a number of factors including (1) the isotopic composition of the water that the roots used, which in turn is affected by precipitation and evaporation and the degree to which this water is influenced by surface and ground water sources, (2) evaporative enrichment in the leaf, (3) biological fractionation processes during the incorporation of water into organic molecules, and (4) isotopic exchange of $\mathrm{H}$ and $\mathrm{O}$ during transfer of the biosynthate from the leaf to the secondary xylem. In contrast, the $\delta^{13} \mathrm{C}$ values of plants depend on (1) the $\delta^{13} \mathrm{C}$ of the atmospheric $\mathrm{CO}_{2}$ used, (2) internal and external $\mathrm{CO}_{2}$ concentration, and (3) biological fractionation processes whereby the enzyme Rubisco fractionates strongly against ${ }^{13} \mathrm{C}$. Using this information, stable isotopes from plant material in general have provided valuable detailed palaeonvironmental insights.

Wood, and more specifically tree rings, has also been used extensively to this end with the main emphasis being on past climate inferences from modern and Quaternary material (up to several 100,000 years; cf. Loader et al. 2003 and references cited therein). Studies focusing on palaeo-, as distinct from past-, climate are more limited and have concentrated predominantly on Tertiary and Cretaceous material (e.g. Lücke et al. 1999).

Past and palaeoclimate studies using stable isotope analyses of fossil wood have to consider inherent molecular heterogeneity of the wood, i.e. the relative abundance of the lignin and different polysaccharide fractions. It is known that these fractions often have different stable isotope compositions (Benner et al. 1987; Poole and van Bergen 2002; Loader et al. 2003). Therefore, isotope determinations of bulk wood samples alone would be directly affected by the actual molecular composition of the material and the abundance of one fraction relative to another (cf. van Bergen and Poole 2002). To overcome this phenomenon most studies use only a single fraction, in most cases cellulose, although lignin as such has also been evaluated to this end (Benner et al. 1987; Spiker and Hatcher 1987; Loader et al. 2003). However, even within the cellulose differentiations are being made and $\alpha$-cellulose is suggested to be the most reliable fraction for $\delta \mathrm{D}, \delta^{13} \mathrm{C}$ and $\delta^{18} \mathrm{O}$ measurements (Loader et al. 1997). Thus, for modern and Quaternary wood material stable isotope measurements of $(\alpha$-)cellulose are preferred. However, for older specimens cellulose might not be preserved or might be chemically (van Bergen 1994) or isotopically changed (Schleser et al. 1999). In such cases research has focused on bulk wood (cf. Gröcke 1998, 2002; Gröcke et al. 1999; Hesselbo et al. 2000), isolated lignin fractions (Spiker and Hatcher 1987) or alternatively compound specific stable isotope measurements of ligno-cellulose derived markers (see later, Poole et al. 2004). Despite the fact that isolated lignin fraction(s) can provide extremely useful data, it must be noted that preferential lignin degradation within secondary xylem cell wall layers (van der Heijden and Boon 1994; van der Heijden et al. 1994) may affect the isotope composition. Therefore, in most cases it is the relative isotopic change between the individual samples, and not the absolute values, that are of importance.

Despite the numerous processes affecting the final isotope composition of wood, $\delta \mathrm{D}$ and $\delta^{18} \mathrm{O}$ data of cellulose have yielded meaningful palaeoclimate information for modern and past specimens (e.g. Lipp et al. 1996; Switsur et al. 1996; Anderson et al. 1998; Waterhouse et al. 2002). The basic premise for this relates to the fact that during evaporation ${ }^{1} \mathrm{H}_{2}^{16} \mathrm{O}$ is preferentially lost. Since temperature strongly affects evaporation, the $\mathrm{H}$ and $\mathrm{O}$ isotope composition can often be linked to temperature. In principal, higher temperatures may cause more evaporation leading to the remaining water, which is subsequently used by the plant, to be $\mathrm{D}$ and ${ }^{18} \mathrm{O}$ enriched $\left(\delta^{18} \mathrm{O}\right.$ values less negative). Hence, when less negative values are measured, in cellulose, higher temperatures can be inferred. Alternatively, humidity will affect the $\delta^{18} \mathrm{O}$ values. For example, Sauer et al. (1997) used cellulose from a number of different tree species growing at sites with varying soil moisture to show 
that trees from the drier sites had less ${ }^{18} \mathrm{O}$ depleted values. Once again absolute values are less important than relative changes since the $\delta^{18} \mathrm{O}$ values of rainwater varies across the world due to the temperature effect on precipitation.

In addition to the $\delta \mathrm{D}$ and $\delta^{18} \mathrm{O}$ results, the $\delta^{13} \mathrm{C}$ data of fossil wood can, in principal, provide insights into the $\delta^{13} \mathrm{C}$ of the atmospheric $\mathrm{CO}_{2}$ at the time the tree grew. For example the increased depletion in ${ }^{13} \mathrm{C}$ of atmospheric $\mathrm{CO}_{2}$ since the industrial revolutions can easily be traced in trees (e.g. Wiesberg 1974). In addition, $\delta^{13} \mathrm{C}$ data can provide information on climate-induced physiological changes such as drought-, or inundation-, related stress (Switsur and Waterhouse 1998). This is because stomatal conductance decreases during drought or inundation forcing a reduction in $\mathrm{Ru}-$ bisco fractionation leading subsequently to less ${ }^{13} \mathrm{C}$ depleted primary biosynthates compared with those formed during normal growth.

To date, we know of no studies using $\delta \mathrm{D}$ and $\delta^{18} \mathrm{O}$ data of pre-Quaternary wood to provide palaeoclimate information and hence for the older fossil wood specimens we will focus on stable carbon isotopes. The main difference between Quaternary and pre-Quaternary wood samples relates (to a greater extent) to the changes in chemical composition during fossilization which in turn will affect the stable isotopic composition (van Bergen and Poole 2002; Poole et al. 2004). During the fossilization process the holocellulose fraction is preferentially degraded relative to the lignin fraction (Hedges et al. 1985). Even within the holocellulose fraction the hemicelluloses are normally degraded faster than the cellulose. This type of chemical taphonomy (van Bergen and Poole 2002) will dramatically affect bulk wood stable isotope measurements because of their different isotope composition of each of these three moieties (Benner et al. 1987; Loader et al. 2003). With regard to carbon, differences of ca. $5 \%$ exist between the three fractions, with hemicellulose being least depleted in ${ }^{13} \mathrm{C}$ whereas lignin is most depleted. If only cellulose is used to determine palaeoclimate it could be assumed that chemical taphonomy is of no significance. However, cellulose is normally not preserved in fossils older than a few million years. Moreover, recent data have implied that cellulose under artificial diagenetic conditions does undergo isotopic changes (Schleser et al. 1999). This is in accordance with detailed molecular data of fossil plant material containing cellulose which indicate that the degree of polymerisation of cellulose decreases during fossilisation (van Bergen 1994; Stankiewicz et al. 1997) which in turn affects the stable isotope composition. Furthermore, relatively low yields during cellulose extraction and the distinct yellow, as opposed to white, colour of the cellulose obtained from pre-Quaternary specimens (Schleser and Helle personal communication) imply significant chemical transformations. Hence, cellulose data of pre-Quaternary samples can be used as long as the taphonomic biases which might affect the isotopic signatures are given due consideration.

Based on the aforementioned biases it is not surprising that most studies of older wood specimens have concentrated on stable carbon isotope measurements of bulk wood samples (Gröcke 1998; Gröcke et al. 1999; Hesselbo et al. 2000). From these latter studies it has become clear that the main palaeoclimatic information to be obtained relates to changes in $\delta^{13} \mathrm{C}$ of atmospheric $\mathrm{CO}_{2}$. In particular Hesselbo et al. (2000) showed that large additions of extreme ${ }^{13} \mathrm{C}$-depleted methane into the atmosphere could be traced in fossilized wood growing at that time. In addition, direct isotopic links between the terrigenous and marine realm have been examined using $\delta^{13} \mathrm{C}$ measurements of fossil wood (Gröcke et al. 1999). However, these were less conclusive since positive isotopes excursions in the marine realm were sometimes being reflected by either positive or negative excursions in the wood data.

Another important factor when using preQuaternary fossil wood for palaeoclimatic inferences is preservation type (i.e. mummified, permineralised or coalified) since the processes involved during these different fossilization pathways have a major impact on the chemical composition (Stout et al. 1988, 1989; van der Heijden and Boon 1994; van der Heijden et al. 1994) which in turn affects the stable carbon isotope contents (Poole et al. 2004). In general, mummified material mostly contains organic moieties directly related to the ligno-cellulose recognized in modern wood specimens. In contrast, coalified and permineralised specimens are mainly composed of primary and secondary transformation products of lignin, i.e. catechols, phenols and naphthols (Poole et al. 2004). Hence, mummified specimens should in principal yield the most representative 
isotope data and as such become the preferred fossil type when using wood to this end. However, relative differences in the preserved chemical fractions such as the amount of polysaccharides vs. lignin, or even the lignin composition itself (van der Heijden and Boon 1994; van der Heijden et al. 1994), in fossil mummified wood still need to be determined as they will affect the bulk stable carbon isotope values (van Bergen and Poole 2002; Poole et al. 2004). With respect to permineralised and coalified material comparisons should be made with material of similar preservation to reduce biases introduced through chemical variation.

A further consideration is taxonomic affinity of the specimens. Stable carbon isotope differences are known to exist between modern tree taxa with the main difference usually at the angiosperm vs. conifer level (Stuiver and Braziunas 1987). Angiosperm wood is generally considered to be more ${ }^{13} \mathrm{C}$ depleted relative to conifer wood. However, the stable carbon isotope data of modern bulk wood samples have been found to be more diverse than previously suggested (Table 1) when climate and leaf morphology are not considered. If temperate rain forest conifer species (Phyllocladus; Podocarpus) are compared with temperate rainforest angiosperm species (Eucryphia; Nothofagus) then differences in $\delta^{13} \mathrm{C}$ are still supported. Moreover, the high $\delta^{13} \mathrm{C}$ values of the wet tropical Iriartea and

Table 1. $\delta^{13} \mathrm{C}$ bulk wood values from a selection of modern woods to illustrate the range exhibited between the generally $\delta^{13} \mathrm{C}$ depleted conifer - vs. the $\delta^{13} \mathrm{C}$ enriched angiosperm wood.

\begin{tabular}{ll}
\hline Taxon & $\delta^{13} \mathrm{C}_{\mathrm{bulk}}$ wood $(\%)$ \\
\hline Conifers & \\
Phyllocladus hypophyllus & -19.3 \\
Pinus cembroides & -21.3 \\
Podocarpus seuoi & -23.3 \\
Pinus cembra & -23.4 \\
Cupressus sempervirens & -24.8 \\
Sequoia sempervirens & -24.8 \\
Araucaria bidwillii & -25.5 \\
Pinus strobus & -27.3 \\
Angiosperms & \\
Illicium yunnanensis & -23.4 \\
Quercus lobra & -23.7 \\
Eucryphia cordifolia & -25.9 \\
Symplocus sp. (Symplocus tenuifolia) & -30.6 \\
Sassafras albidum & -27.1 \\
Nothofagus antarctica & -27.8 \\
Astrocaryum murumuru & -28.6 \\
Attalea excelsa & -29.3 \\
Iriartea deltoidea & -30.2 \\
\hline
\end{tabular}

Attalea may be explained by the low wettability of the leaves of these palm species. Thus, when climate change time series are studied using different taxa, the taxonomic effect may influence interpretations. Therefore, it is preferable to use the same taxon whenever possible. A palaeoclimatic study by Hesselbo et al. (2000) successfully used isotopic date and eliminated taxonomic and preservation biases by focusing on Jurassic jet material. Jet is fossilised conifer wood which acquired the physical appearance of obsidian. Specimens preserved as jet no longer contain ligno-cellulose but are solely composed of phenols (Poole, Kool and van Bergen, unpublished results) which are secondary lignin degradation products. Hence, the absolute isotope data will have been affected by associated chemical transformations. However, since all material preserved as jet will have undergone similar alterations during fossilization, and thus have the same chemical composition, the relative stable carbon isotope changes can provide meaningful palaeoclimatic information showing in this case the large changes in $\delta^{13} \mathrm{C}$ of atmospheric $\mathrm{CO}_{2}$. Where taxonomic status or preservation cannot be kept constant a correction for the chemical composition needs to be made and the $\delta^{13} \mathrm{C}$ of the wood and $\delta^{13} \mathrm{C}$ of the atmosphere back calculated (cf. Poole et al. 2004).

\section{Palaeoclimatic signals from compound specific stable isotope analyses of wood}

An alternative solution to overcome the biases associated with chemical heterogeneity of fossil wood specimens is the use of compound specific stable isotopes. Over the last decade, stable isotope analyses of individual organic compounds for palaeoclimate studies have gained significant momentum. Initially these studies concentrated on $\delta^{13} \mathrm{C}$ measurements, but compound-specific $\delta \mathrm{D}$ analyses are now also commonplace (e.g. Xie et al. 2000). The majority of data are derived from solvent soluble lipids, with only few studies evaluating macromolecular material. The main reason being that macromolecules first have to be transformed to yield meaningful smaller building blocks that can be analysed using gas chromatography. For fossil plant material this can be achieved using chemolysis or pyrolysis (van Bergen 1999). 
Compound-specific analyses of fossil wood are rare and only focus on stable carbon isotopes (Poole and van Bergen 2002; Poole et al. 2004). This approach subjects the fossil wood specimens to off-line pyrolysis (for analytical details see Poole and van Bergen 2002) which yields characteristic products that can be directly assigned to either polysaccharides (mainly cellulose), lignin or lignin degradation products (Poole and van
Bergen 2002; Poole et al. 2004) each with a characteristic isotopic signal. So far fossil wood samples of different taxonomic status and preservation types have been successfully studied using this approach. A typical example of an angiosperm wood specimen is shown in Figure 2a revealing an abundance of different pyrolysis products. However, it should be emphasised that in order for these, relatively polar, products to be analysed, (a)

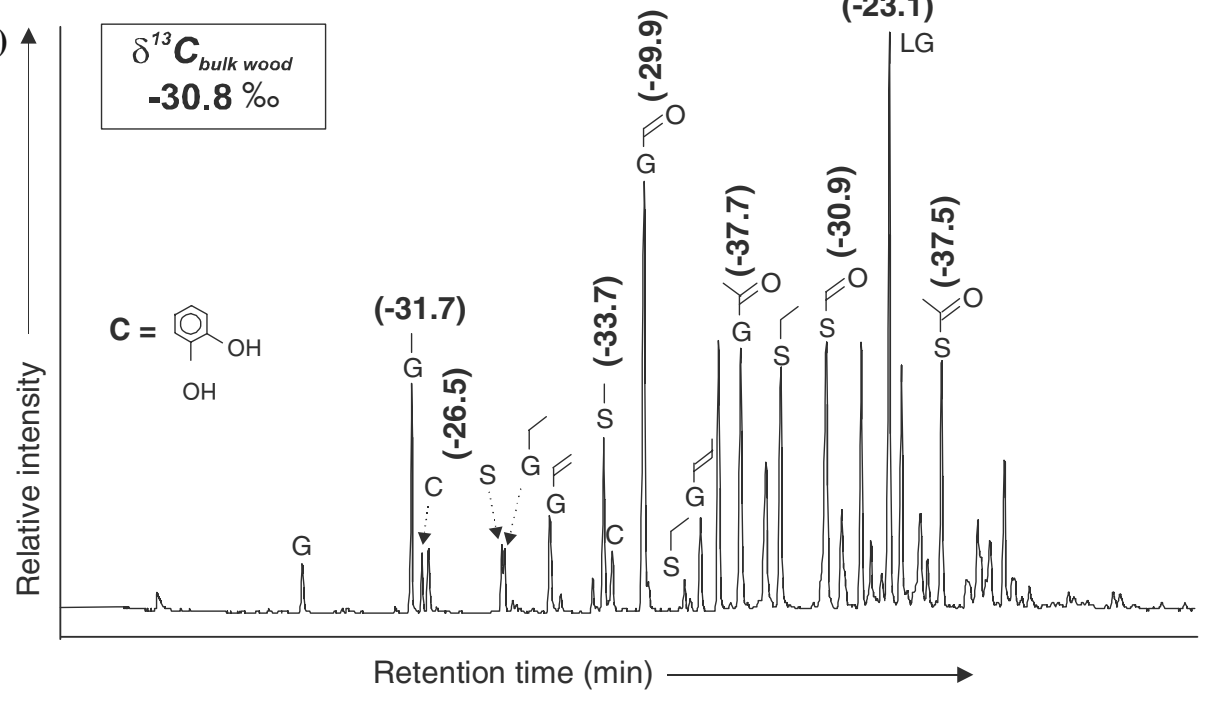

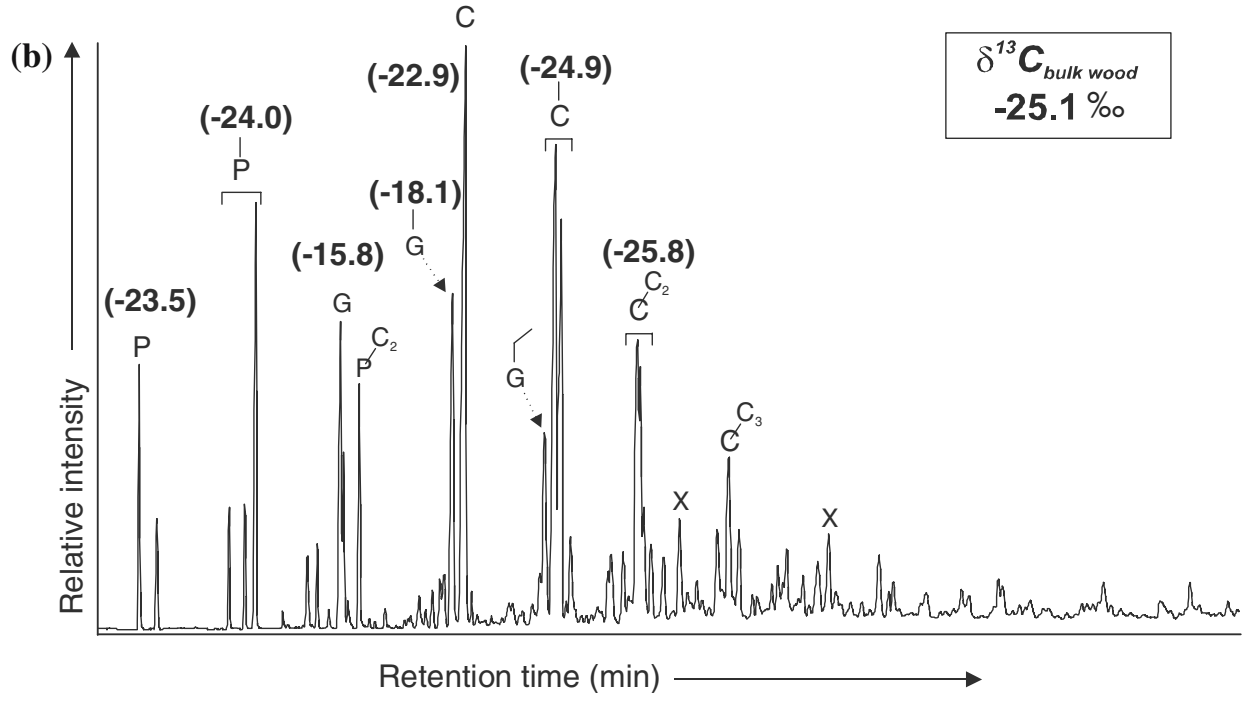

Figure 2. Off-line pyrolysate products, analysed as BSTFA derivatised compounds, of (a) a mummified Peruvian (Pliocene-Miocene) fossil wood specimen showing evidence of polysaccharides (LG) and lignin (G and S) units characteristic of well preserved lignocellulose as well as some degradation products (C); (b) a permineralised fossil (Cretaceous) wood specimen from Antarctica showing evidence of degraded lignin based on the abundance of the degradation products $(\mathrm{C}, \mathrm{P})$ and the relatively small amounts of $\mathrm{G}$. Key: LG, levoglucosan; P, phenol; C, catechol; G, guaiacol; S, syringol. Side chains indicated are attached at carbon number 4 para to the $\mathrm{OH}$ group (cf. Appendix I). 
they first need to be derivatised using a carboncontaining reagent, such as BSTFA. Thus the measured data have to be corrected for the carbon added during the derivatisation procedure. An important observation is the distinct isotopic difference between the cellulose-derived product, levoglucosan, and the lignin-derived methoxyphenols, i.e. $\mathrm{G}$ and $\mathrm{S}$ products. As predicted from the stable carbon isotope data of different ligno-cellulose fractions, the cellulose compounds are ${ }^{13} \mathrm{C}$ enriched relative to the lignin markers. This clearly provides evidence that the off-line pyrolysis method used leaves the isotopic signals intact. This distinct offset has been observed in all the mummified wood specimens studied to date (Poole et al. 2004). Thus for mummified specimens along a time series one could use a single compound, i.e. levoglucosan and/or 2-methoxyphenol (guaiacol) to determine excursions in $\delta^{13} \mathrm{C}$ of atmospheric $\mathrm{CO}_{2}$. This would circumvent variations in bulk wood measurements caused by compositional differences (i.e. relative contribution of polysaccharides over lignin; Poole et al. 2004). With regard to lignin markers the same derivative in each case must be measured because isotopic differences, relating to the number of side-chain carbons, amongst these methoxyphenols can be significant (Figure 2a).

Initially, it had been assumed by the authors that the use of the same organic compound through geological time would provide the most reliable data for palaeoclimate reconstructions. In particular, the distinct lignin marker 2-methoxyphenol (guaiacol) was considered a suitable product since this compound could be found in specimens as old as the middle Cretaceous. The off-line pyrolysis data of these older, permineralised, specimens yielded, apart from the lignin markers, mainly primary and secondary lignin degradation products, i.e. catechols and phenols, respectively, (Figure $2 \mathrm{~b}$ ). The compound specific results of these products yielded intriguing information as significant isotopic differences, of up to $17 \%$, were found between compound classes (methoxyphenols vs. catechols, phenols). However, in stark contrast to what was expected, i.e. lignin markers being ${ }^{13} \mathrm{C}$ depleted (cf. Figure 2b), the lignin-derived products, (guaiacol) were extremely ${ }^{13} \mathrm{C}$ enriched when compared with the catechols, the primary lignin degradation products. This phenomenon has been observed in all permineralised wood specimens that yielded lignin markers with the majority of the organic material being composed of lignin-degradation products. Lignin degradation to catechols is known to cause an isotopic shift but only of $1 \%$ causing the catechol to be slightly less ${ }^{13} \mathrm{C}$ depleted (Galimov 1985). Thus this process alone could not explain the guaiacol values measured. Thus, guaiacol cannot be used when the sample has been drastically changed. In contrast, stable isotope results from the primary lignin degradation product, catechol, appears more stable and thus might be a more appropriate target compound. Based on the above the isotopic composition of catechols from a series of permineralised fossil wood specimens from Antarctica was evaluated. The compound specific isotope data revealed large changes in the isotope composition that were similar for catechol as well as its methyl derivatives showing true isotope changes (Figure 3). The main shifts occurred in the middle Eocene and during the $\mathrm{K} / \mathrm{T}$ boundary implying dramatic alterations of the $\delta^{13} \mathrm{C}$ of the atmosphere.

\section{Conclusion}

Fossil wood is a unique data store of palaeoclimatic information through geological time (Figure 4). In order to reconstruct palaeoclimate data obtained from physiognomic and chemical characters of fossil material should always be used in conjunction with other evidence, either from sedimentology or in combination with other fossil material such as leaves, wherever possible. Moreover, the safeguards detailed above should be adhered to wherever possible to ensure the data obtained is not only meaningful but also useful for future studies when the understanding of modern responses of trees to climate is more fully understood. Interpretations based on physiognomic (i.e. anatomical and morphological) characters need to acknowledge evolutionary factors coupled with intrinsic natural variation that can bias interpretation. Moreover, care is needed when extrapolating ideas derived from modern systems to palaeo-environments and climates which may have no analogue on Earth today. Compound specific stable carbon isotope analyses of fossil wood specimens can yield new insights with respect to palaeoclimate reconstructions. 

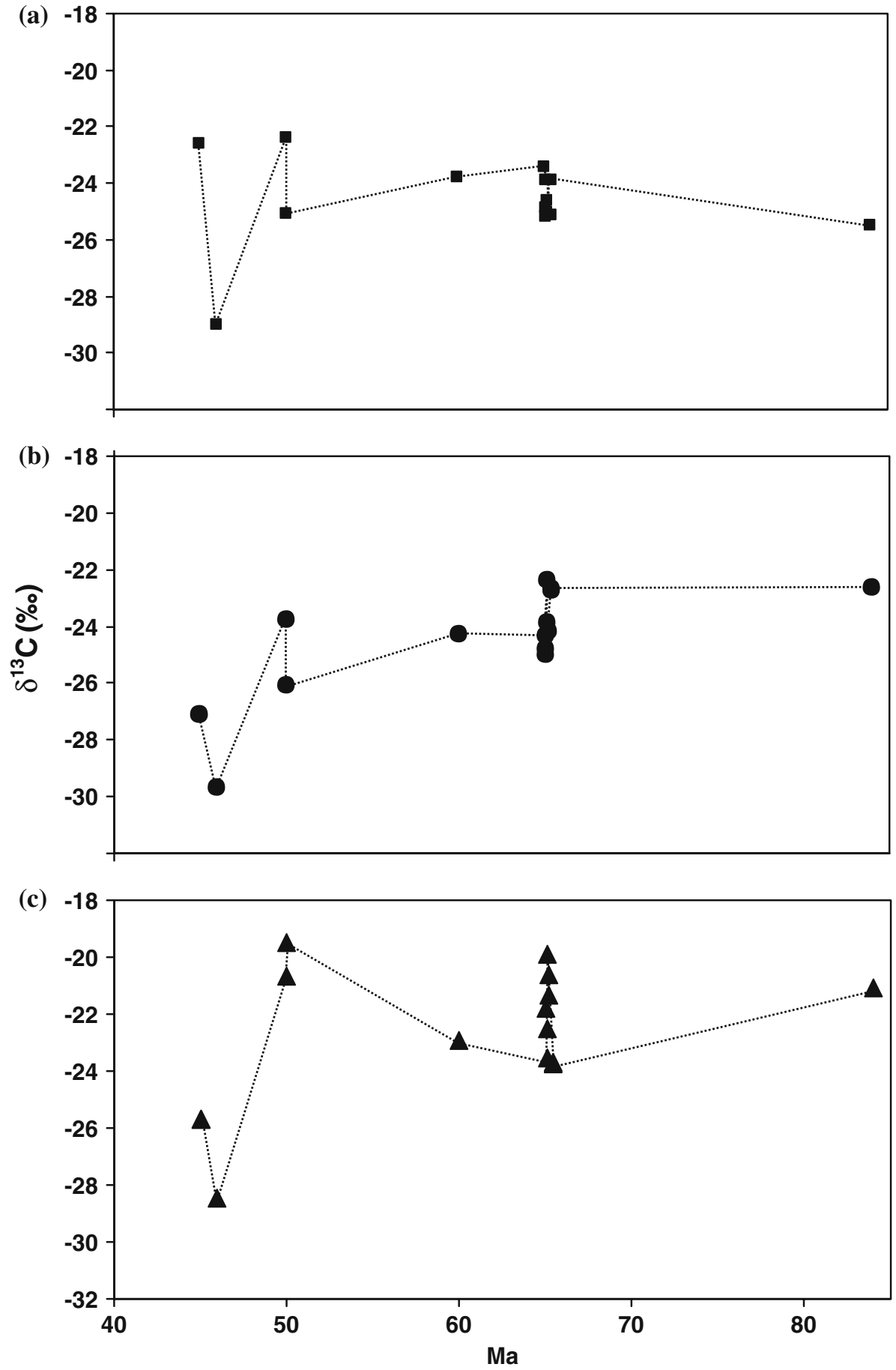

Figure 3. Changes in stable carbon isotope composition of catechol, methylcatechol and bulk organic matter from Antarctic permineralized wood specimens revealing the large shift probably related to shift in $\delta^{13} \mathrm{C}$ of atmospheric $\mathrm{CO}_{2}$, (a) bulk, (b) catechol, (c) methylcatechols. 


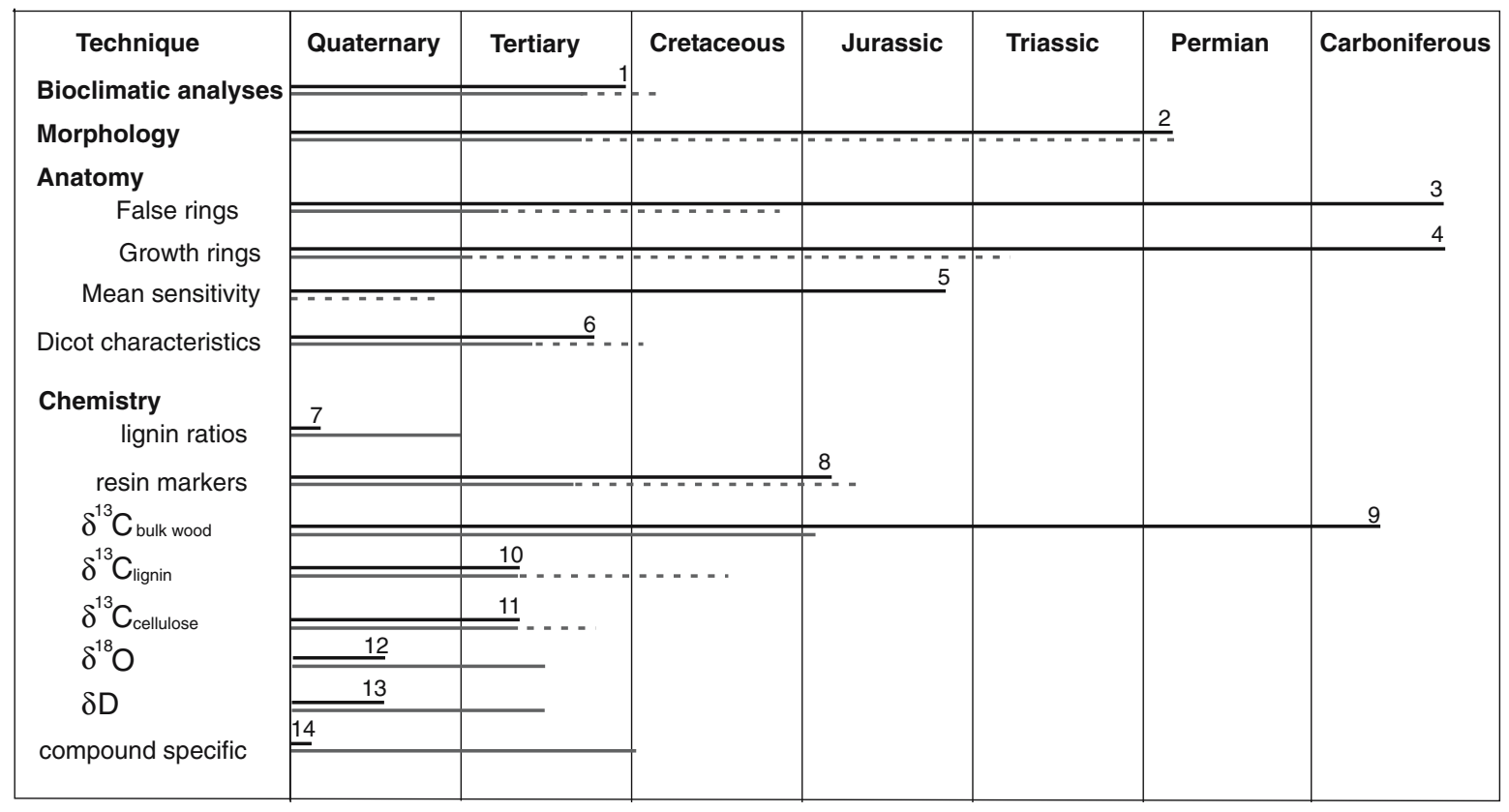

Figure 4. Diagrammatic representation of the applicability of different approaches using fossil wood to determine palaeoclimatic factors through geological time. Solid black line indicates the record from selected published literature (not exhaustive) from: 1 Poole et al. (2001, 2003). 2 Francis (1988), Fielding and Alexander (2001), 3 Falcon-Lang (1999a), Morgans (1999), Morgans et al. (1999), Taylor et al. (1992), 4 Falcon-Lang (1999a, b), Cúeno et al. (2003), Taylor et al. (1992), Francis (1984, 1986), Ash and Creber (1992), Francis et al. (1994), Jefferson and Taylor (1983), Yadav and Bhattacharyya (1996), Poole and Francis (1999), 5 Morgans et al. (1999), Francis (1986), 6 Francis and Poole (2002), Hunt and Poole (2003), Poole et al. (2005), 7 Hedges et al. (1982), Goñi (1997), Kuder and Kruge (1998), 8 van Aarssen et al. (2000), Otto et al. (1994), 9 Jones (1994), Hesselbo et al. (2000), Gröcke et al. (1999), van Bergen and Poole (2002), Poole et al. 2004, 10 Spike and Hatcher (1987), Loader et al. (2003), 11 Spiker and Hatcher (1987), Bates and Spiker (1992), Lücke et al. (1999), 12 Anderson et al. (1998), Sauer et al. (2000), 13 Lipp et al. (1996), Mayr et al. (2003), 14 Poole et al. (2004). Solid grey line indicates certain applicability of each methodology, dotted grey line indicates the possible applicability if all caveats are acknowledged and discussed (authors' opinion).

However, in addition to the prerequisites outlined for the physiognomic studies, the type of chemical preservation as well at the actual compound measured has to be taken into consideration. Therefore, although wood offers great potential for palaeoclimatic determinations, we recommend a comprehensive, interdisciplinary approach using all biotic and abiotic evidence available when trying to retrodict climates through the geological past.

\section{Acknowledgements}

This research was made possible by funding through the Natural Environmental Research
Council (UK), NWO (ALW 809.32.004, NL), Percy Sladen Memorial Fund (UK) and a British Council grant JRP472. The authors would like to thank Johan Kool (Utrecht University), D. Makaham (NHN-Utrecht), M. Tabecki (British Antarctic Survey) for help with material preparation over the years. Professor G. Schleser (Research Centre Jülich $\mathrm{GmbH}$ ), Dr G. Helle (Research Centre Jülich $\mathrm{GmbH}$ ), Dr U. Sass-Klaassen (Wageningen University), Dr D. Cantrill (Swedish Museum of Natural History) are thanked for valuable discussions. Professor RS Hill, Dr M. Silman and the Bristish Antarctic Survey are thanked for the invitations to collect wood samples from various field locations. 


\section{Appendix}

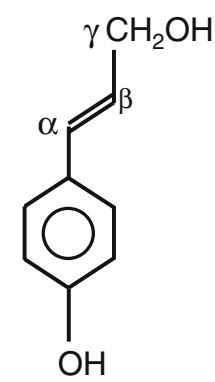

p-coumaryl alcohol

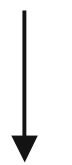

p-Hydroxyphenyl (P)

\section{Lignin building blocks}<smiles>COc1cc(C=CCO)ccc1O</smiles>

Coniferyl alcohol

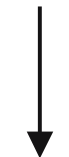

Guaiacyl (G)<smiles>COc1cc(C=CCO)cc(OC)c1O</smiles>

Sinapyl alcohol

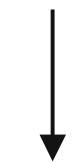

Syringyl (S)

\section{References}

Aloni R. 2001. Foliar and axial aspects of vascular differentiation: hypothesis and evidence. J. Plant Growth Regul. 20: $22-34$.

Ammons R., Fritz W.J., Ammons R.B. and Ammons A. 1987. Cross-identification of ring signatures in Eocene trees (Sequoia magnifica) from the Speciman Ridge locality of the Yellowstone fossil forests. Palaeogeogr. Palaeoclimatol. Palaeoecol. 60: 97-108.

Anderson W.T., Bernasconi S.M., McKenzie J.A. and Saurer M. 1998. Oxygen and carbon isotopic record of climatic variability in tree-ring cellulose (Picea abies): an example from central Switzerland (1913-1195). J. Geophys. Res. 103: 635-636.

Ash S.R. and Creber G.T. 1992. Paleaoclimatic interpretation of the wood structures of the trees in the Chinle Formation (Upper Triassic), Petrified Forest National Park, Arizona, USA. Palaeogeogr. Palaeoclimatol. Palaeoecol. 96: 299-317.

Baas P. 1973. The wood anatomical range in Ilex (Aquifoliaceae) and its ecological significance. Blumea 21: 193-258.

Baas P. 1976. Some functional and adaptive aspects of vessel member morphology. In: Baas P., Bolton A.J. and Catling D.M. (eds), Leiden Botanical Series 3, Wood Structure in Biological and Technological Research Wood Structure, Leiden University Press, The Hague, pp. 157-181.

Baas P. 1986. Ecological patterns of xylem evolution. In: Givnish J. (ed.), On the Economy of Plant Form and Function, Cambridge University Press, Cambridge, pp. $327-352$.

Baas P. and Schweingruber F.H. 1987. Ecological trends in the wood anatomy of trees, shrubs and climbers from Europe. IAWA Bull. n.s. 8: 245-274.

Baas P., Ewers F.W., Savis S.D. and Wheeler E.A. 2004. Evolution of xylem physiology. In: Hemsley A.R. and Poole I. (eds), Linnean Society Symposium Series 21, Evolution of Plant Physiology, Elsevier, Amsterdam, pp. 273-295.
Bates A.L. and Spiker E.C. 1992. Chemical changes and carbon isotope variations in a cross-section of a large Miocene gymnospermous log. Chem. Geol. 101: 247-254.

Benner R., Fogel M.L., Sprague E.K. and Hodson R.E. 1987. Depletion of ${ }^{13} \mathrm{C}$ in lignin and its implications for stable carbon isotope studies. Nature 329: 708-710.

Boon J.J., Stout S.A., Genuit W. and Spackman W. 1989. Molecular paleobotany of Nyssa endocarps. Acta Bot. Neerl. 38: 391-404.

Borchert R. 1999. Climatic periodicity, phenology and cambium activity in tropical dry forest trees. Int. Assoc. Wood Anat. J. 20: 239-247.

Briffa K.R., Schweingruber F.H., Jones P.D., Osborn T.J., Harris I.C., Shiyatov S.G., Vaganov E.A. and Grudd H. 1998. Trees tell of past climates: but are they speaking less clearly today?. Phil. Trans. Roy. Soc. London B 353: 65-73.

Brison A-L., Philippe M. and Thevenard F. 2001. Are Mesozoic wood growth rings climate-induced? Paleobiology 27: 531538.

Carlquist S. 1975. Ecological Strategies in Xylem Evolution. University of California Press, Berkeley.

Carlquist S. 1977. Ecological factors in wood evolution: a floristic approach. Am. J. Bot. 64: 887-896.

Carlquist S. 1988. Comparative Wood Anatomy Systematic Ecological and Evolutionary aspect of Dicotyledon Wood. 1st ed. Springer Verlag, Berlin.

Carlquist S. 2001. Comparative Wood Anatomy Systematic Ecological and Evolutionary aspect of Dicotyledon Wood 2nd ed. Springer Verlag, Berlin.

Chaloner W.G. and Creber G.T. 1973. Growth rings in fossil woods as evidence of past climates. In: Tarling D.H. and Runcorn S.K. (eds), Implications of Continental Drift to Earth Sciences, Academic Press, New York, pp. 425-437.

Chapman J.L. 1994. Distinguishing internal developmental characteristics from external palaeoenvironmental effects in fossil wood. Rev. Palaeobot. Palynol. 81: 19-32. 
Collinson M.E. 1986. Use of modern generic names for plant fossils. In: Spicer R.A. and Thomas B.A. (eds), Systematic and Taxonomic Approaches in Palaeobotany, Clarendon Press, Systematics Association Special Volume 31, Oxford pp. 91-104.

Creber G.T. 1977. Tree rings: a natural data storage system. Biol. Rev. 52: 349-383.

Creber G.T. and Chaloner W.G. 1984. Influence of environmental factors on the wood structure of living and fossil trees. Bot. Rev. 50: 357-448.

Creber G.T. and Chaloner W.G. 1990. Environmental influences on cambial activity. In: Iqbal M. (ed.), The Vascular Cambium, John Wiley and Sons Inc., New York, pp. 159 199.

Creber G.T. and Francis J.E. 1999. Fossil tree-ring analysis: palaeodendrology. In: Jones T.P. and Rowe N.P. (eds), Fossil Plants and Spores Modern Techniques, Geological Society London, London, pp. 245-250.

Chowdhury K.A. 1964. Growth rings in tropical trees and taxonomy. J. Indian Bot. Soc. 43: 334-343.

Demko T.M., Dubiel R.F. and Parrish J.T. 1998. Plant taphonomy in incised valleys: implications for interpreting paleoclimate from fossil plants. Geology 26: 1119-1122.

den Outer R.W. and van Veenendaal W.L.H. 1976. Variation in wood anatomy of species with a distribution covering both rainforest and savannah areas of the Ivory Coast, WestAfrica. Leiden Bot. Series 3: 182-195.

Douglass A.E. 1928. Climate cycles and tree growth: a study of the annual rings of trees in relation to climate and solar activity. Vol II. Carnegie Institute, Washington Publ. 289.

Falcon-Lang H.J. 1999a. The Early Carboniferous (CourceyanArunian) monsoonal climate of the British Isles: evidence from growth rings in fossil woods. Geol. Magazine 136: 177-187.

Falcon-Lang H.J. 1999b. The early Carboniferous (AsbianBrigantian) seasonal tropical climate of northern Britain. Palaios 14: 116-126.

Falcon-Lang H.J. 2000a. The relationship between leaf longevity and growth ring markedness in modern conifer woods and its implications for palaeoclimatic studies. Palaeogeogr. Palaeoclimatol. Palaeoecol. 160: 317-328.

Falcon-Lang H.J. 2000b. A method to distinguish between woods produced by evergreen and deciduous coniferopsids on the basis of growth ring anatomy: a new palaeoecological tool. Palaeontology 43: 785-793.

Falcon-Lang H.J. 2003. Do tree rings in fossil woods give a palaeoclimatic signal? (Conference abstract). IAWA J. 24: 316.

Falcon-Lang H.J. 2005a. Intra-tree variability in wood anatomy, and its implications for fossil wood systematics and palaeoclimatic studies. Palaeontology 48: 171-183.

Falcon-Lang H.J. 2005b. Global climate analysis of growth rings in woods and its implications for deep time paleoclimate studies. Paleobiology 31: 434-444.

Falcon-Lang H.J. and Cantrill D.J. 2000. Cretaceous (Late Albian) coniferales of Alexander Island, Antarctica. I. Wood taxonomy, a quantitative approach. Rev. Palaeobot. Palynol. 111: 1-17.

Falcon-Lang H.J., Cantrill D.J. and Nichols G.J. 2001. Biodiversity and terrestrial ecology of a mid Creaceous, high latitude floodplain, Alexander Island, Antarctica. J. Geol. Soc. London 158: 709-724.
February E. 1993. Sensitivity of xylem vessel size and frequency to rainfall and temperature implications for palaeontology. Palaeontol. Afr 30: $91-95$.

Fielding C.R. and Alexander J. 2001. Fossil tees in ancient fluvial channel deposits: evidence of seasonal and longer-term climatic variability. Palaeogeogr. Palaeoclimatol. Palaeoecol. 170: $59-80$.

Fielding C.R., Alexander J. and Newman-Sutherland E. 1997. Preservation of in situ, arborescent vegetation and fluvial bar construction in the Burdekin river of north Queensland, Australia. Palaeogeogr. Palaeoclimatol. Palaeoecol. 135: 123-144.

Figueiral I. and Mosbrugger V. 2000. A review of charcoal analysis as a tool for assessing Quaternary and Tertiary environments achievements and limits. Palaeogeogr. Palaeoclimatol. Palaeoecol. 164: 397-407.

Francis J.E. 1984. The seasonal environment of the Purbeck (Upper Jurassic) fossil forests. Palaeogeogr. Palaeoclimatol. Palaeoecol. 48: 285-307.

Francis J.E. 1986. Growth rings in Cretaceous and Tertiary wood from Antarctica and their palaeoclimatic implications. Palaeontology 29: 665-684.

Francis J.E. 1988. A 50-million year old fossil forest from Strathcona Fiord, Ellesmere Island, Arctic Canada: evidence for a warm polar climate. Arctic 41: 314-318.

Francis J.E. and Poole I. 2002. Cretaceous and Tertiary climates of Antarctica: evidence from fossil wood. Palaeogeogr. Palaeoclimatol. Palaeoecol. 182: 47-64.

Francis J.E. Woolfe K.J. Arnott M.J. and Barrett P.J. 1994. Permian climates of the southern margins of Pangea: evidence from fossil wood in Antarctica. Soc. Petrol. Mem. 17: 275-282.

Fritts H.C. 1976. Trees Rings and Climate. Academic Press, New York London.

Fritts H.C. 1991. Reconstructing Large-Scale Climate Patterns from Tree-ring Data. A Diagnostic Analysis. University of Arizona Press, Tuscon.

Gartner B.L. 1995. Patterns of xylem variation within a tree and their hydraulic and mechanical consequences. In: Gartner B.L. (ed.), Plant Stems: Physiology and Functional Morphology, Academic Press, London, pp. 125-149.

Galimov E.M. 1985. The Biological Fractionation of Isotopes. Academic Press, Orlando.

Goñi M.A. 1997. Record of terrestrial organic matter composition in amazon fan sediments. In: Flood R.D., Piper D.J.W., Klaus A. and Peterson L.C. (eds), Proceedings of the Ocean Drilling Program, Scientific Results, Vol. 155, pp. $519-530$

Gregory-Wodzicki K.M. 2001. Paleoclimatic implications of tree-ring growth characteristics of $34.1 \mathrm{Ma}$ Sequoiaoxylon pearsallii from Florissant Colorado. Proceedings of the Denver Museum of Nature and Science 4(1), pp. 163-186.

Greguss P. 1972. Xylotomy of Living Conifers. Akademia Kiado, Budapest.

Grice K., van Aarssen B.G.K., Jiang D., Alexander R. and Kagi R.I. 2001. Stable carbon isotpic compositions and distributions of higher plant biomarkers reflecting palaeoclimate changes during the Jurassic. 20th International meeting on organic geochemistry, Abstracts Volume 1. Université Henri Poincaré, Vandoeuvre. p. 175.

Gröcke D.R. 1998. Carbon-isotope analyses of fossil plants as a chemostratigraphic and palaeoenvironmental tool. Lethaia 31: $1-13$. 
Gröcke D.R. 2002. The carbon isotope composition of ancient $\mathrm{CO}_{2}$ based on higher-plant organic matter. Phil. Trans. Roy. Soc. London A 360: 633-658.

Gröcke D.R., Hesselbo S.P. and Jenkyns H.C. 1999. Carbonisotope composition of Lower Cretaceous fossil wood, oceanatmosphere chemistry and relation to sea-level change. Geology 27: 155-158.

Hedges J.I., Lowie G.L., Ertel J.R., Barbour R.J. and Hatcher P.G. 1985. Degradation of carbohydrates and lignins in buried woods. Geochim. Cosmochim. Acta 49: 701-711.

Hedges J.I., Ertel J.R. and Leopold E.B. 1982. Lignin geochemistry of a Late Quaternary core from Lake Washington. Geochim. Cosmochim. Acta 46: 1869-1877.

Henry H.A.L. and Aarssen L.W. 1999. The interpretations of stem diameter-height allometry in trees: biomechanical constraints, neighbour effects or biased regressions?. Ecol. Lett. 2: 89-97.

Herendeen P.S. 1991. Lauraceous wood from the mid-Cretaceous Potomac group of eastern North America: Paraphyllanthoxylon marylandense sp. nov. Rev. Palaeobot. Palynol. 69: $277-290$.

Hesselbo S.P., Gröcke D.R., Jenkyns H.C., Bjerrum C.J., Farrimond P., Morgans Bell H.S. and Green O.R. 2000. Massive dissociation of gas hydrate during a Jurassic oceanic anoxic event. Nature 406: 392-395.

Hook D.D. 1984. Adaptations to flooding with fresh water. In: Kozlowski T.T. (ed.), Flooding and Plant Growth, Academic Press, London, pp. 265-293.

Hunt R.J. and Poole I. 2003. Revising Palaeogene West Antarctic climate and vegetation history in light of new data from King George Island. In: Wing S.L., Gingerich P.D., Schmitz B. and Thomas E. (eds), Causes and Consequences of Globally Warm Climates in the Early Paleogene. Geological Society of America Special Paper 369, pp. 395-412.

Jacoby G.C. 1989. Overview of tree ring analysis in tropical regions. IAWA J. 10: 99-108.

Jane F.W. 1962. The Structure of Wood. A\&C Black, London.

Jefferson T.J. 1982. The early Cretaceous forests of Alexander Island, Antarctica. Palaeontology 25: 681-708.

Jefferson T.J. and Taylor T.N. 1983. Permian and Triassic woods from the Transantarctic Mountains: paleoenvironmental indicators. Antarct. J. US 1983: 55-57.

Jones T.P. $1994 .{ }^{13} \mathrm{C}$ enriched Lower Carboniferous fossilplants from Donegal, Ireland: carbon isotope constraints on taphonomy, diagenesis and palaeoenvironment. Rev. Palaeobot. Palynol. 81: 53-64.

Keller A.M. and Hendrix M.S. 1997. Palaeoclimatological analysis of a Late Jurassic petrified forest, Southeastern Mongolia. Palaios 12: 282-291

Kershaw A.P. and Nix H.A. 1988. Quantitative palaeoclimatic estimates from pollen data using bioclimatic profiles of extant taxa. J. Biogeogr. 15: 589-602.

Koizumi A., Takata K., Yamashita K. and Nakada R. 2003. Anatomical characteristics and mechanical properties of Larix sibirica grown south-central Siberia. IAWA J. 24: 355 370.

Kuder T. and Kruge M.A. 1998. Preservation of biomolecules in sub-fossil plants from raised peat bogs - a potential paleoenvironmental proxy. Org. Geochem. 29: 1355-1368.

Kumagai H., Sweda T., Hayashi K., Satoru K., Basinger J.F., Shibuya M. and Fukaoa Y. 1995. Growth-ring analysis of
Early Tertiary conifer woods from the Canadian High Arctic and its palaeoclimatic implications. Palaeogeogr. Palaoeclimatol. Palaeoecol. 116: 247-262.

La Marche V.C. 1982. Sampling strategies. In: Hughes M.K., Kelly P.M., Pilcher J.R. and La Marche V.C. (ed), Climate from Tree Rings, Cambridge University Press, Cambridge, p. 4.

Langenheim J.H. 2003. Plant Resins: Chemistry, Evolution, Ecology, and Ethnobotany. Timber Press, Cambridge.

Larsen R.R. 1967. Silvicultural control on the characteristics of woods used for furnish. In: ANON (ed), Proceedings of the 4th TAPPI Forest Biology Conference. Pulp and Paper Research Institute of Canada, Quebec, pp. 143-150.

Larson P.R. 1956. Discontinuous growth rings in suppressed slash pine. Trop. Woods 104: 80-99.

Liang M-M., Bruch A., Collinson M.E., Mosbrugger V., Li C.S., Sun Q.-G. and Hilton J. 2003. Testing the climatic estimates from different palaeobotanical methods: an example from the Middle Miocene Shanwang flora of China. Palaeogeogr. Palaeoclimatol. Palaeoecol. 198: 279-301.

Lindorf H. 1994. Eco-anatomical wood features of species from a very dry tropical forest. IAWA J. 15: $361-384$

Lipp J., Trimborn P., Graf W., Edwards T. and Becker B. 1996. Climate signals in a ${ }^{2} \mathrm{H}$ and ${ }^{13} \mathrm{C}$ chronology $(1882-1989)$ from tree rings of spruce (Picea abies L.), Schussbach forest, Germany. In: Dean J.S., Meko D.M. and Swetnam T.W. (eds), Tree Rings, Environment, and Humanity. Radiocarbon. Department of Geosciences, The University of Arizona, Tucson, pp. 603-610.

Loader N.J., Robertson I., Barker A.C., Switsur V.R. and Waterhouse J.S. 1997. An improved technique for the batch processing of small whole wood samples to $\alpha$-cellulose. Chem. Geol. 136: 313-317.

Loader N.J., Robertson I. and McCarroll D. 2003. Comparison of stable carbon isotope ratios in the whole wood, cellulose and lignin of oak tree-rings. Palaeogeogr. Palaeoclimatol. Palaeoecol. 196: 395-407.

Lücke A., Helle G., Schleser G.H., Figueiral I., Mosbrugger V., Jones T.P. and Rowe N.P. 1999. Environmental history of the German Lower Rhine Embayment during the Middle Miocene as reflected by carbon isotopes of brown coal. Palaeogeogr. Palaeoclimatol. Palaeoecol. 154: 339-352.

Mayr C., Frenzel B., Friedrich M., Spurk M., Stichler W. and Trimborn P. 2003. Stable carbon- and hydrogen-isotope ratios of subfossil oaks of southern Germany: methodology and application to a composite record for the Holocene. Holocene 13: 393-402.

Monserud R.A. 1986. Time-series analysis of tree ring chronologies. Forest Sci. 32: 349-372.

Morgans H.S. 1999. Lower and Middle Jurassic woods of the Cleveland Basin (North Yorkshire), England. Palaeontology 42: $303-328$.

Morgans H.S., Hesselbo S.P. and Spicer R.A. 1999. The seasonal climates in the Early-Middle Jurassic, Cleveland Basin, England. Palaios 14: 261-272.

Mosbrugger V. 1999. The nearest living relative method. In: Jones T.P. and Rowe N.P. (eds), Fossil Plants and Spores Modern Techniques, The Geological Society, London, pp. 261-265.

Mosbrugger V. and Utescher T. 1997. The coexistence approach - method for quantitative reconstructions of 
Tertiary terrestrial palaeoclimate data using plant fossils. Palaeogeogr. Palaeoclimatol. Palaeoecol. 134: 61-86.

Otto A. and Wilde V. 2001. Sesqui-, di- and triterpenoids as chemosystematic markers in extant conifers - a review. Bot. Rev. 67: $141-238$.

Otto A., Walther H. and Püttmann W. 1994. Molecular composition of a leaf- and root-bearing Oligocene oxbow lake clay in the Weisselster Basin, Germany. Org. Geochem. 22: $275-286$.

Poole I. 2000. Variation - nature's spanner or an unrecognised tool? Palaios Online 15: 1-2.

Poole I. and van Bergen P.F. 2002. Carbon isotope ratio analysis of organic moieties from fossil mummified wood: Establishing optimum conditions for off-line pyrolysis extraction using GC/MS. Rapid Commun. Mass Spectrom. 16: 1-6.

Poole I. and Francis J.E. 1999. Reconstruction of Antarctic palaeoclimates using angiosperm wood anatomy. Acta Palaeobot. Suppl. 2: 173-179.

Poole I., Hunt R.J. and Cantrill D.J. 2001. A fossil wood flora from King George Island: ecological implications for an Antarctic Eocene vegetation. Ann. Bot. 88: 33-54.

Poole I., Mennega A.M.W. and Cantrill D.J. 2003. Valdivian ecosystems in the late Cretaceous and early Tertiary of Antarctica as evidenced from fossil wood. Rev. Palaeobot. Palynol. 124: 9-27.

Poole I., Richter H. and Francis J.E. 2000. Gondwanan origins for Sassafras (Lauraceae)? evidence from Late Cretaceous fossil wood of Antarctica. IAWA J. 21: 463-475.

Poole I., Cantrill D.J. and Utescher T. 2005. Reconstructing Antarctic palaeoclimate from wood floras - a comparison using multivariate anatomical analysis and the Coexistence Approach. Palaeogeogr. Palaeoclimatol. Palaeoecol. 222: 95-121.

Poole I., Dolezych M., Kool J., van der Burgh J. and van Bergen P.F. Do stable carbon isotopes of brown coal woods record changes in Miocene palaeoecology? Palaeogeogr. Palaeoclimatol. Palaeoecol. (submitted).

Poole I., van Bergen P.F., Kool J., Schouten S.S. and Cantrill D. 2004. Molecular isotopic heterogeneity of fossil organic matter: implications for $\delta^{13} \mathrm{C}_{\text {biomass }}$ and $\delta^{13} \mathrm{C}_{\text {palaeoatmosphere }}$ proxies. Org. Geochem. 35: 1261-1274.

Reid E.M. and Chandler M.E.J. 1933. The Flora of the London Clay. British Museum (Natural History), London.

Saurer M., Aellen K. and Siegwolf R. 1997. Correlating $\delta^{13} \mathrm{C}$ and $\delta^{18} \mathrm{O}$ in cellulose of trees. Plant Cell Environ. 20: 1543-1550.

Saurer M., Cherubini P. and Siegwolf R. 2000. Oxygen isotopes in tree rings of Abies alba: the climatic significance of interdecadal variations. J. Geophys. Res. Atmos. 105: $12461-$ 12470.

Savidge R.A. 1996. Xylogenesis, genetic and environmental regulation - a review. IAWA Bull. 10: 170-174.

Savva Y.V., Schweingruber F.H., Vaganov E.A. and Milyutin L.I. 2003. Influence of climate change on tree-ring characteristics of Scots pine provenances in southern Siberia (foreststeppe). IAWA J. 24: 371-383.

Schleser G.H., Frielingsdorf J. and Blair A. 1999. Carbon isotope behaviour in wood and cellulose during artificial aging. Chem. Geol. 158: 121-130.

Schulman E. 1938. Classification of false annual rings in Monterey pine. Tree-ring Bull. 4: 4-7.
Schweingruber F.H. 1993. Morphological, Anatomical and Tree-ring Analytical Characteristics of Trees Frequently used in Dendrochronology (Springer Series in Wood science). Springer Verlag, GmbH \& Co, Berlin, Heidelberg.

Sheng Hu F., Hedges J.I., Gordon E.S. and Brubaker L.B. 1999. Lignin biomarkers and pollen in postglacial sediments of an Alaskan lake. Geochim. Cosmochim. Acta 63: 1421-1430.

Simoneit B.R.T. 1998. Biomarker PAHs in the environment. In: Hutzinger, O. (ed.), The Handbook of Environmental Chemistry. PAHs and Related Compounds. 3, Part I, A.H Neilson (ed.), Springer Verlag, Berlin, pp. 175-221.

Spiker E.C. and Hatcher P.G. 1987. The effects of early diagenesis on the chemical and stable carbon isotopic composition of wood. Geochim. Cosmochim. Acta 51: 1385-1391.

Stankiewicz B.A., Mastalerz M., Kruge M.A., van Bergen P.F. and Sadowska A. 1997. A comparative study of modern and fossil cone scales and seeds of conifers: a geochemical approach. New Phytol. 135: 375-393.

Stone E.C. and Vasey R.B. 1968. Preservation of coast redwood on alluvial flats. Science 159: 157-161.

Stout S.A., Boon J.J. and Spackmans W. 1988. Molecular aspects of the peatification and early coalification of angiosperm and gymnosperm woods. Geochem. Cosmochem. Acta 52: $405-414$

Stout S.A., Spackman W., Boon J.J., Kistemaker P.G. and Bensley D.F. 1989. Correlations between the microscopic and chemical changes in wood during peatification and early coalification: a canonical variant study. Int. J. Coal Geol. 13: $41-64$.

Strackee J. and Jansma E. 1992. The statistical properties of 'mean sensitivity' a reappraisal. Dendrochronologia 10: 121 135.

Stuiver M. and Braziunas T.F. 1987. Tree cellulose ${ }^{13} \mathrm{C} /{ }^{12} \mathrm{C}$ isotope ratios and climate change. Nature 328: 58-60.

Switsur R. and Waterhouse J. 1998. Stable isotopes in tree-ring cellulose. In: Griffiths H. (ed.), Stable Isotopes - Integration of Biological, Ecological and Geochemical Processes, Bios Scientific, Oxford, pp. 303-321.

Switsur R., Waterhouse J.S., Field E.M. and Carter A.H.C. 1996. Climatic signals from stable isotopes in oak trees from East Anglia, Great Britain. In: Dean J.S., Meko D.M. and Swetnam T.W. (eds), Tree Rings, Environment, and Humanity Radiocarbon, Department of Geosciences, The University of Arizona, Tucson, pp. 637-645.

Waterhouse J.S., Switsur V.R., Barker A.C., Carter A.H.C. and Robertson I. 2002. Oxygen and hydrogen isotope ratios in tree rings: how well do models predict observed values? Earth Planet. Sci. Lett. 201: 421-430.

Tardif J., Camarero J.J., Ribas M. and Gutierrez E. 2003. Spatiotemporal variability in tree growth in the Central Pyrenees: Climatic and site influences. Ecol. Monogr. 73: 241-257.

Taylor E.L., Taylor T.N. and Cúneo N.R. 1992. The present is not the key to the past: a polar forest from the Permian of Antarctica. Science 257: 1675-1677.

Terral J.-F. and Mengüal X. 1999. Reconstruction of Holocene climate in southern France and eastern Spain using quantitative anatomy of olive wood and archaeological charcoal. Palaeogeogr. Palaeoclimatol. Palaeoecol. 153: 71-92.

Tomlinson P.B. and Craighead F.C. 1972. Growth ring studies on the native trees of sub-tropical Florida. In: Ghouse 
A.K.M. and Yunus M. (eds), KA Chowdhury Commemoration Volume, Tata McGraw-Hill, New Delhi, pp. 39-51.

van Aarssen B.G.K., Alexander R. and Kagi R.I. 2000. Higher plant biomarkers reflect palaeovegetation changes during Jurassic times. Geochim. Cosmochim. Acta 64: 1417-1424. van Bergen P.F. 1994. Paleaobotany of Propagules: An Investigation combining Microscopy and Chemistry. University of London, UK, PhD thesis.

van Bergen P.F. 1999. Pyrolysis and chemolysis of fossil plant remains: applications to palaeobotany. In: Jones T.P. and Rowe N.P. (eds), Fossil Plants and Spores: Modern Techniques, The Geological Society, London, pp. 143-148.

van Bergen P.F. and Poole I. 2002. Stable carbon isotopes in wood: A clue to palaeoclimate?. Palaeogeogr. Palaeoclimatol. Palaeoecol. 182: 31-45.

van Bergen P.F., Collinson M.E., Briggs D.E.G., de Leeuw J.W., Scott A.C., Evershed R.P. and Finch P. 1995. Resistant biomacromolecules in the fossil record. Acta Bot. Neerl. 44: 319-342.

van Bergen P.F., Flannery M.B., Poulton P.R. and Evershed R.P. 1998. Organic Geochemical Studies of Soils From Rothamsted Experimental Station: III Nitrogen-Containing Macromolecular Moieties in Soil Organic Matter from Geescroft Wilderness. In: Stankiewicz B.A. and van Bergen P.F. (eds), ACS Symposium Series, 707, Nitrogen-Containing Macromolecules in the Bio- and Geosphere, Oxford University Press, New York, pp. 321-338.

van Bergen P.F., Blokker P., Collinson M.E., Sinninghe Damsté J.S. and de Leeuw J.W. 2004. Structural biomacromolecules in plants: What can be learnt from the fossil record? In: Hemsley A.R. and Poole I. (eds), Linnean Society Symposium Series, 21, Evolution of Plant Physiology, Elsevier, Amsterdam, pp. 133-154.

van der Heijden E. and Boon J.J. 1994. A combined pyrolysis mass spectrometric and light microscopic study of peatified Calluna wood isolated from raised peat deposits. Org. Geochem. 22: 903-919.

van der Heijden E., Bouman F. and Boon J.J. 1994. Anatomy of recent and peatified Calluna vulgaris stems: implications for coal maceral formation. Int. J. Coal Geol. 25: $1-25$.

Vetter R.E. and Botosso P.C. 1989. Remarks on age and growth rate determination of Amazonian trees. IAWA Bull. n.s. 10: $135-145$.

Wheeler E.A. and Baas P. 1991. A survey of the fossil record for dicotyledonous wood and its significance for evolutionary and ecological wood anatomy. IAWA Bull. 12: 275-332.

Wheeler E.A. and Baas P. 1993. The potential and limitations of dicotyledonous wood anatomy for climatic reconstructions. Paleobiology 19: 487-498.
Wheeler E.A. and Manchester S.R. 2002. Woods of the Eocene nut beds Flora Clarno formation, Oregon USA. IAWA J. Suppl. 3: 1-188.

Wiemann M.C., Dilcher D.L. and Manchester S.R. 2001. Estimation of mean annual temperature from leaf and wood physiognomy. Forest Sci. 47: 141-149.

Wiemann M.C., Wheeler E.A., Manchester S.R. and Portier K.M. 1998. Dicotyledonous wood anatomical characters as predictors of climate. Palaeogeogr. Palaeoclimatol. Palaeoecol. 139: 83-100.

Wiemann M.C., Manchester S.R. and Wheeler E.A. 1999. Paleotemperature estimation from dicotyledonous wood anatomical characters. Palaios 14: 459-474.

Wiesberg L. 1974. Die ${ }^{13} \mathrm{C}-\mathrm{Abnahme}$ in Holz von Baumjahresringen, eine Untersuchung zur anthropogenen Beeinflussung des $\mathrm{CO}_{2}$-Haushaltes der Atmosphäre. Dissertation, RWTH Aachen.

Wilson K. and White D.J.B. 1986. The Anatomy of Wood: Its Diversity and Variability. Stobart \& Son Ltd, London.

Woodcock D.W. 1994. Occurrence of woods with a gradation in vessel diameter across a ring. IAWA J. 15: 277-385.

Woodcock D.W. and Ignas C.M. 1994. Prevalence of wood characters in eastern North America: what characters are most promising for interpreting climates from fossil wood? Am. J. Bot. 81: 1243-1251.

Worbes M. 1985. Structural and other adaptations to long-term flooding by trees in Central Amazonia. Amazonia 9: 459 484.

Worbes M. 1989. Growth rings, increment and age of trees in inundation forests, savannahs and a mountain forest in the Neotropics. IAWA Bull. n.s. 10: 109-122.

Worbes M. 1995. How to measure growth dynamics in tropical trees - a review. IAWA J. 16: 337-351.

Worbes M. 1999. Annual growth rings, rainfall dependent growth and long term growth pattern in tropical trees from Caparo Forest Reserve in Venezuela. J. Ecol. 87: $391-403$.

Xie S., Nott C.J., Avsejs L.A., Volders F., Maddy D., Chambers F.M., Gledhill A., Carter J.F. and Evershed R.P. 2000. Palaeoclimate records in compound-specific $\delta \mathrm{D}$ values of a lipid biomarker in ombrotrophic peat. Org. Geochem. 31: $1053-1057$.

Yadav R.R. and Bhattacharyya 1996. Climatic significance of growth rings in Mesozoic woods from India. Palaeobotanist 45: 57-63.

Yao Z.Q., Lui L.J. and Zhang S.A. 1994. Permian wood from western Henan, China: implications for palaeoclimatological interpretations. Rev. Palaeobot. Palynol. 80: 277-290.

Zobel B.J. and van Buijtenen J.P. 1989. Wood Variation: Its Causes and Controls. Springer-Verlag, Berlin. 